\title{
Competing assessments of market-driven, sustainability-centered, and stakeholder-focused approaches to the customer-brand relationships and performance
}

\section{Highlights}

- A stakeholder-focused strategy generally results in better performance than a marketdriven or sustainability-centered strategy.

- For tangible product firms (manufacturing firms), a sustainability-centered strategy is more effective for firm performance than a market-driven or stakeholder-focused strategy.

- A firm’s strategy accounts for 89 to 96 percent of its business performance; meaning firms can only control their own performance to that extent. 
Competing assessments of market-driven, sustainability-centered, and stakeholder-focused approaches to the customer-brand relationships and performance

\section{Graphical Abstract}

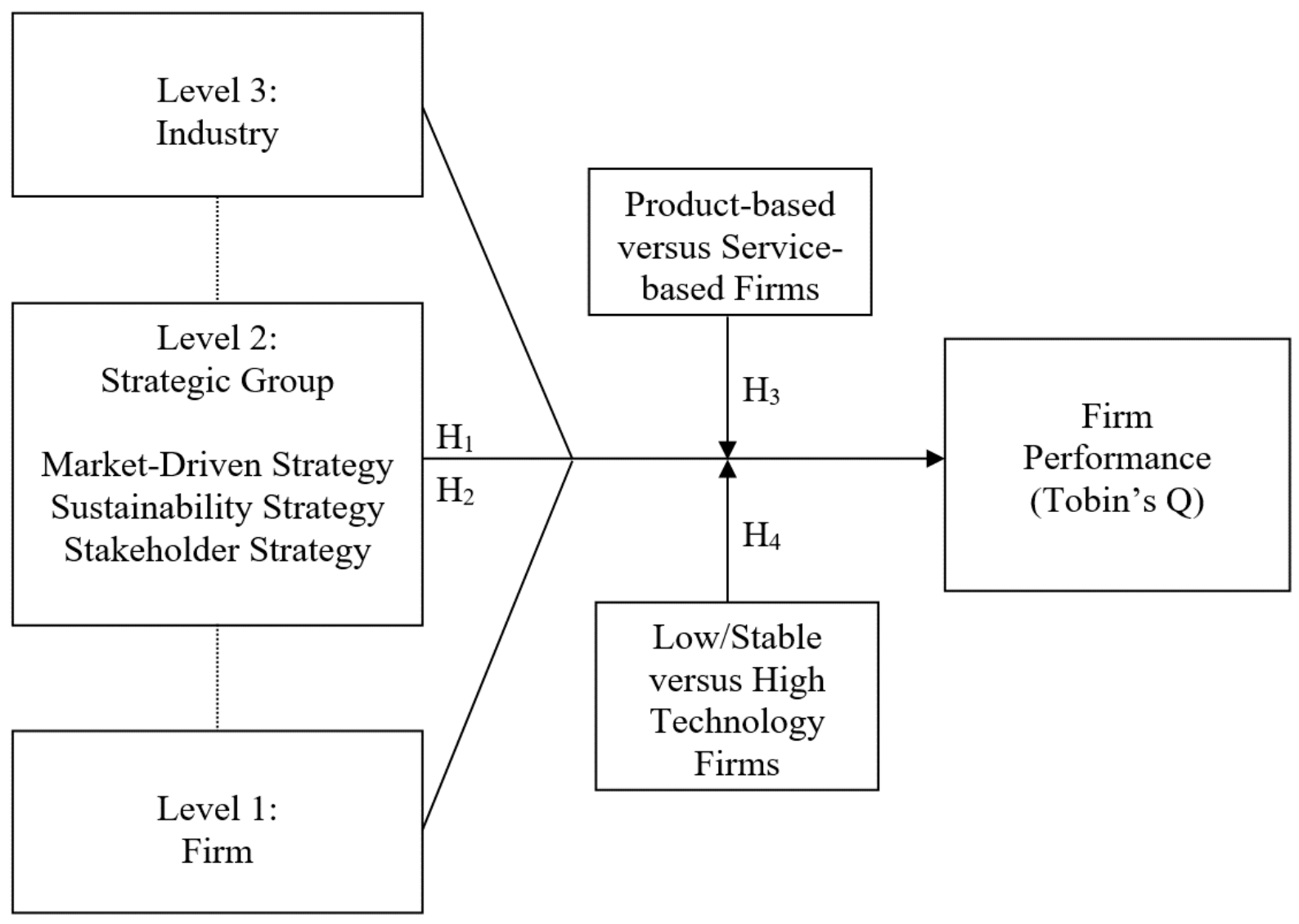

Time Period: $t_{0}$ to $t_{1}$ Time Period: $t_{2}$ to $t_{3}$ 


\title{
Competing assessments of market-driven, sustainability-centered, and stakeholder-focused approaches to the customer-brand relationships and performance
}

\begin{abstract}
For over two decades, marketing strategy has centered on the importance of being primarily market-driven to achieve superior customer-brand relationships and firm performance. However, changes in the business environment have prompted some organizations to embrace newer approaches to marketing strategy development, such as being sustainability-centered or stakeholder-focused. Using a competing analysis framework, we assess the marketing performance implications of these three approaches to marketing strategy development (i.e., market-driven, sustainability-centered, and stakeholder-focused) while accounting for other firm and industry effects. The hypotheses are tested using secondary data involving 1,716 firms over a four-year period. The results indicate that, in general, placing more emphasis on a broad set of stakeholders (i.e., customers, employees, suppliers, shareholders, communities, and regulators) when developing marketing strategy is more important in achieving superior performance than is engaging in market-driven or sustainability-centered efforts. These findings support previous research that social responsibility associated with a stakeholder-focused strategy has a positive impact on customer-brand relationships resulting in performance. The results also indicate that distinctive marketing strategies exist among tangible product firms, service firms, low/stable tech firms, and high-tech firms.
\end{abstract}

Keywords:

market-driven; sustainability; stakeholders; hierarchical linear modeling; marketing strategy 


\section{Introduction}

Strategic marketing researchers have long been interested in uncovering why some organizations outperform others (i.e., fostering and maintaining superior customer relationships). The relationship marketing literature suggests that marketing strategies enacted and executed by firms deeply shape the customer relationships with the firms (Colgate \& Danaher, 2000). Research over the last two decades in marketing strategy - based primarily on the market orientation literature - has consistently found that those firms that acquire information about the needs and wants of their customers and respond to this information by developing and implementing strategies that target those customer needs outperform firms that do otherwise (e.g., Jaworski \& Kohli, 1993; Kirca, Jayachandran, \& Bearden, 2005; Ruekert, 1992). Specifically, doing so enhances healthy and enduring customer-brand relationships.

However, this traditional, market-driven approach to developing strong brand relationships has recently, mainly in the last decade, been challenged by broader performance frameworks that include social responsibility and ethics. This also results from the increasing attention which customers have started giving to sustainable/green products and corporate social responsibility. ${ }^{1}$ To cope with the changes in the business environment, some firms have shifted from the traditional market-driven approach (e.g., Day, 1994) to embrace newer approaches to marketing strategy development aimed at “doing good” (Sen \& Bhattacharya, 2001). In doing so, consumerbrand relationships have effectively become associated with ethics and social responsibility (Park, Kim, \& Kwon, 2017), in essence integrating established frameworks from marketing strategy on one hand and ethics and social responsibility on the other. More importantly, the brand value associated with business ethics has been found to influence customers' perceptions of the brand

\footnotetext{
${ }^{1}$ https://www.forbes.com/sites/sarahlandrum/2017/03/17/millennials-driving-brands-to-practice-socially-responsible-marketing
} 
(Vitell et al., 2016), which in turn impacts customers' relationships with the brand and organizational performance (Fernández \& Pinuer, 2016). Additionally, familiarity with social responsibility has been shown to have a significant effect on the corporate identity, which in turn affects purchase interaction (Prabu \& Kline, 2005).

Sustainability is one approach to social responsibility that can be linked to marketing strategies. The sustainability-centered approach focuses on delivering economic, social, and environmental benefits simultaneously (e.g., Huang \& Rust, 2011; Hunt, 2011). For instance, a firm adopting the sustainability-centered approach may develop processes that minimize waste and design products with low life-cycle costs, which can provide additional value to consumers and ultimately lead to a competitive advantage (e.g., Hart, 1995; Sheth, Sethia, \& Srinivas, 2011). Sustainability is one of the most visible components of social responsibility that can differentiate products and corporate identity to create social value, quality, and consumer loyalty (Ferrell, Fraedrich, \& Ferrell, 2017). Maio (2003) positions sustainability and social responsibility with having major implications for brand management, and the image of the brand permeates all corporate behaviors. More explicitly, by acknowledging a brand's efforts on sustainability improvement (i.e., producing sustainable green products and socially responsible products), customers are likely to perceive the brand more favorably, thus fostering a better customer-brand relationship such as more positive word of mouth (WOM) and more repurchases (Castaldo, Perrini, Misani, \& Tencati, 2009).

A broader approach to social responsibility and marketing strategy development is the stakeholder-focused approach. This approach consists of developing mutually trusting and cooperative relationships with multiple stakeholder groups (Jones, 1995). This requires firms to be cognizant of the interests of different stakeholders and to develop strategies that are focused on 
addressing those interests (cf. Smith, Drumwright, \& Gentile, 2010). A stakeholder refers to "any group or individual who can affect or is affected by the achievement of the organization's objectives” (Freeman, 1984, p. 46), including the primary stakeholders of customers, employees, suppliers, shareholders, communities, and regulators (Clarkson, 1995). According to the stakeholder-focused approach, firms that implement strategies that are centered on meeting stakeholder demands enhance brand equity (Torres, Bijmolt, Tribó, \& Verhoef, 2012), achieve a good reputation, reduce contracting costs, obtain a competitive advantage (e.g., Jones, 1995), and are rewarded with superior financial performance (e.g., Berman, Wicks, Kotha, \& Jones, 1999; Choi \& Wang, 2009) and improved shareholder value (Hillman \& Keim, 2001). Maignan, Gonzalez-Padron, Hult, \& Ferrell (2011) operationalize this approach and empirically demonstrate that stakeholder orientation has a strong positive association with market performance, financial performance, reputation, and employee commitment. Related to this research, although customer relationship seems to associate with one of the six primary stakeholder segments, firms' endeavors to satisfy other stakeholders' needs may offer additional value to their customers (Castaldo et al., 2009). For instance, when firms strive to meet the regulations required by the government, they provide extended protections to their customers, which may be valued by customers and exchanged for a premium price and loyalty. In other words, the relationships between customers and brands can be strengthened via a stakeholder-focused strategy.

Interestingly, even though these different approaches to developing marketing strategies have been examined independently (e.g., Daub \& Ergenzinger, 2005; Greenley \& Foxall, 1998; Jaworski \& Kohli, 1993), there are no studies that assess and compare the relative effects of these approaches on customer-brand responses and firm performance (cf. Ferrell, Gonzalez-Padron, Hult, \& Maignan, 2010). This void is significant because, unless the three approaches are 
considered simultaneously, researchers and executives alike are left unsure about the approaches' relative merit in cultivating a better customer-brand relationship and ultimately explaining performance. In the world where firms battle for a better consumer-brand relationship (Kumar, 2015) and more approaches to developing marketing strategies (i.e., sustainability-centered or stakeholder-focused) have emerged and gained popularity, a remaining practical dilemma becomes more prominent: which approach should executives follow when developing marketing strategies to achieve better performance? This question is crucial for firms' survival and prosperity. Furthermore, calls for research that broadens the scope of marketing strategy to emphasize additional stakeholders beyond a select few (e.g., Bhattacharya \& Korschun, 2008; Hult, Mena, Ferrell, \& Ferrell, 2011; Smith et al., 2010) have been largely ignored. Stakeholderfocused and sustainability-centered approaches have been linked directly to ethics and social responsibility. The existence of these strategies can be examined for their relationship to both social and financial performance.

To fill this gap, this research aims to achieve the following objectives. First, we assess which marketing strategy development approach (i.e., market-driven, sustainability-centered, or stakeholder-focused) is relatively more important to achieve superior performance, while accounting for other firm and industry effects. Our fundamental contention is that developing and deploying marketing strategies shape brand images and value propositions, the content that gets communicated to customers, and products/services offered by brands, all of which eventually alter customers' perceptions of and experience with the firms and brands. Thus, different marketing strategy approaches nurture various customer-brand relationships and result in variations in firm performance. Second, we further examine the stakeholder-focused approach - being the broadest marketing strategy of the three studied - by analyzing the differential effects of this form of 
marketing strategy across tangible product and service firms and across low/stable and high technology firms.

To do this theoretically, we draw on long-covered topics in marketing strategy, such as market orientation and marketing capabilities (market-driven approach), along with more recently emphasized marketing strategy areas such as marketing exchanges with multiple stakeholders (stakeholder-focused approach) and adherence to the triple bottom line rooted in the sustainability and corporate social responsibility literatures (sustainability-centered approach). To accomplish our objectives empirically, we also draw on the strategic group literature (e.g., Fiegenbaum \& Thomas, 1995) to delineate the three strategic groups that correspond to the market-driven, stakeholder-focused, and sustainability-centered approaches. In addition, we select a broad firm performance indicator (i.e., Tobin’s Q) over a more narrowly focused customer-related performance indicator (i.e., customer satisfaction), in that Tobin's Q is a logical outcome of how well firms are doing with their customers (Rubera \& Kirca, 2017; Wang \& Kim, 2017), and prior marketing strategy studies have commonly used Tobin's Q as their performance indicator (Vomberg, Homburg, \& Bornemann, 2015). Moreover, the forward-looking nature of Tobin's Q (Vomberg, Homburg, \& Bornemann, 2015) can capture the long-term impact of marketing strategies (i.e., Huang, Zhu, \& Brass, 2017). This is extremely important in our context because it may take time for the three approaches studied to reveal their impacts on changing customers' perceptions and evaluation of brands, and this forward-looking indicator can reflect these impacts more precisely. Also, the firm and industry levels are included as control levels (i.e., the firm level is a lower level phenomenon in relation to strategic groups while the industry level is higher; Short, Ketchen, Palmer, \& Hult, 2007) as these have been found to have significant effects on firm performance (e.g., Short et al., 2007). The relationships studied are depicted in Figure 1. We test 
the model using a sample of firms from manufacturing and services industries $(n=1,716)$ with data from a four-year period.

\section{Insert Figure 1 about here}

\section{Theoretical foundation and hypotheses}

\subsection{Marketing strategies, strategic groups, and firm performance}

The notion that a firm's economic and social performance is influenced by the strategy the firm adopts has been studied in the strategic groups literature (e.g., Barney \& Hoskisson, 1990; Bhattacharya \& Korschun, 2008; Caves \& Porter, 1977; Fiegenbaum \& Thomas, 1990; Lewis \& Thomas, 1990; Nair \& Kotha, 2001; Porter, 1979; Vorhies \& Morgan, 2003). Supporters contend that strategic group membership, along with its related collective behavior, is a main driver of durable performance differences among firms within an industry (e.g., Mehra, 1996). A strategic group is defined as a cluster of firms competing in the same industry that implement similar strategies (Porter, 1980). Firms within a strategic group closely resemble each other but differ from firms outside the group on key strategic dimensions such as marketing approaches, innovation, and scales of activity (Porter, 1979). Due to their similarity in structure, group members are likely to recognize their mutual dependence, respond in the same manner to competitive changes, and accurately anticipate each other's reactions (Caves \& Porter, 1977). This behavioral congruence suggests that group members act as a reference group (Fiegenbaum \& Thomas, 1995). Firms benchmark group members and adjust their marketing strategies toward the group target. Market-driven, sustainability-centered, and stakeholder-focused groups need to be benchmarked to determine if they can have a positive effect on social and economic performance. 
In addition, the performance of these strategic groups has important implications for public policy decisions and incentives for socially responsible business practices.

The literature on strategic groups has identified two explanations for variation in performance outcomes across groups within an industry: the presence of mobility barriers (Caves \& Porter, 1977) and the existing conditions of rivalry (Cool \& Dierickx, 1993). Mobility barriers are factors that impede firms from moving from one strategic position to another (Porter, 1980). These mobility barriers represent an investment in a collective capital asset whose benefits are enjoyed among the firms within the group (McGee \& Thomas, 1986). This translates into a relative cost advantage for such firms over competitors in other groups, which would have to engage in costly investments to overcome the barriers and enter the group (e.g., implement a similar marketing strategy). Given that these investments are generally risky and the benefits gained from them may not compensate for the costs incurred, they are expected to deter a firm's efforts to change groups, i.e., change from one marketing strategy to another (cf. Porter, 1979). As a result, firms within a group have low costs associated with replicating the actions of their group members while firms outside the group may have a substantial cost disadvantage that impedes marketing imitation (Hatten \& Hatten, 1987). In short, mobility barriers prevent firms in lowperforming groups from shifting into high-performing groups, thereby explaining critical differences in performance (Nair \& Kotha, 2001; Porter, 1980). Mobility could be a significant barrier to the interests of society if resources are needed to shift to groups with a sustainability or stakeholder focus. This could call for incentives from public policy decisions such as tax policies, regulations, and legislation.

Intergroup rivalry in an industry is a function of market interdependence among groups (i.e., the degree to which different strategic groups are targeting the same customers), the strategic 
distance between groups (i.e., the degree to which marketing strategies differ), and the number and size of the groups (Porter, 1979). According to Porter (1980), a particular strategic group will be most exposed to intergroup rivalry when it faces a larger number of groups that are relatively equal in size, targets the same market segments, and implements different marketing strategies. Excessive intergroup rivalry can reduce a firm’s profit (Nair \& Kotha, 2001). Intragroup rivalry can also have important implications for the performance of the firms (cf. Cool \& Dierickx, 1993). Specifically, firms within a strategic group (i.e., with a certain marketing strategy) may generate above-normal returns to the extent that the group structure hinders the emergence of perfect competition within it (Nair \& Kotha, 2001).

Essentially, when a firm develops and deploys one type of marketing strategy in the marketplace, customers' perceptions of and experience with the firm may be altered accordingly (Colgate \& Danaher, 2000), thus updating their relationships with the firm and ultimately influencing firm performance. In this research, we argue that this influence of marketing strategy on firm performance is a function of the strategically relevant characteristics that define strategic group membership, such as focusing simultaneously on multiple stakeholders’ interests (stakeholder-focused strategic group), targeting the marketplace via market orientation efforts (market-driven strategic group), or concentrating on sustainable development (sustainabilitycentered strategic group). Each strategy type’s focus resonates among firms in today’s marketplace and offers unique marketing strategy-making and implementation guidelines. Specifically, each marketing strategy type requires a different set of strategies, and any variation in performance can be explained by the effectiveness of the marketing action signified by each approach (Hatten \& Hatten, 1987). In the following sections, we describe the three different 
strategic types (stakeholder-focused, market-driven, and sustainability-centered) and explain how each influences customer perceptions and relationships, and eventually, firm performance.

\subsubsection{Stakeholder-focused strategy}

From a strategy development standpoint, firms adopting a stakeholder-focused strategy are highly oriented toward addressing the interests of multiple stakeholders. Freeman (1984) saw the stakeholder concept as going beyond profit maximization to encompass all groups with a stake in the organization. Stakeholder theory holds that a particular group can be identified as a stakeholder that merits managerial attention if it possesses at least one of the following attributes: power, legitimacy, and urgency (Mitchell, Agle, \& Wood, 1997). We concentrate on primary stakeholders, those that are crucial to the firm's survival and continued market success (Clarkson, 1995). Primary stakeholders center on six segments in the marketplace and include customers, employees, suppliers, shareholders, regulators, and communities. Drawing on resource dependence theory, the importance of the six stakeholders lies in their capacity to furnish resources that are critical to the firm's ongoing operations (Pfeffer \& Salancik, 1978). It is the dependence of the firm on such actors for resources that provide them with power over the firm (Frooman, 1999). In turn, the possession of power classifies these actors as stakeholders worthy of managerial attention (Mitchell, Agle, \& Wood, 1997).

Stakeholder concepts are being integrated into marketing frameworks. A stakeholder perspective is seen as compatible with Service-Dominant (S-D) logic in co-creation with stakeholder domains, forming part of the marketing system (Frow \& Payne, 2011). Since marketing is no longer a separate business function, there is a general management responsibility to integrate co-creation (S-D) logic into a broad network enterprise to include the interests of the different stakeholders (Lusch \& Webster, 2011). Working with stakeholders to co-create values 
and co-develop solutions to problems is seen as key to a stakeholder framework. Abela and Murphy (2008) view emerging S-D logic as reducing or eliminating tensions between ethical and financial performance. Shifting from profit maximization to co-creation of value becomes a tangible resource to strengthen the integration of all the stakeholders. Rather than viewing stakeholders as constituents, stakeholders are viewed as co-creators of value to the firm (Freeman \& Stewart, 2006).

Hence, firms that simultaneously attend to the needs of the six primary stakeholders deliver more value and achieve superior firm performance (Donaldson \& Preston, 1995). Specifically, relational interactions with the primary stakeholders can develop intangible, socially complex resources, such as reputation and brand equity, which can, in turn, create value (Hillman \& Keim, 2001). Because of the causal ambiguity of these strategic resources as well as their path-dependent dimension, they are difficult to replicate (Harrison, Bosse, \& Phillips, 2010; Kull, Mena, \& Korschun, 2016). In the context of strategic groups, these investments represent mobility barriers that impede firms outside the stakeholder-focused strategic group from imitating strategic decisions without considerable costs and significant elapsed time (McGee \& Thomas, 1986). These barriers enable the firms within the group to sustain their advantages over those firms adopting other strategies (Porter, 1979).

Perceptions of a firm's social responsibility stance rather than profit maximization are influenced by marketing strategy related to branding, reputation building, and communications (Stanaland, Lwin, \& Murphy, 2011). There can be negative customer-brand attitudes when there are ethical transgressions (Trump, 2014). It has been found that after misconduct associated with a brand there is a negative impact on repurchase intentions (Huber, Vollhardt, Matthes, \& Vogel, 2010). An example could be Volkswagen's emission defeat device scandal. The company's 
reputation crumbled after it used software to detect when the vehicle was undergoing emissions testing, which adversely affected the company's relationship with its existing and prospective customers. This was confirmed by VW America’s former Chief Executive Officer, Martin Winterkorn, who said the company "had broken the trust of our customers and the public." This example illustrates that the consequences of failing to recognize the importance of primary stakeholders (i.e., customers, regulators, shareholders, and communities) include damaged customer-brand relationships and firm performance.

\subsubsection{Market-driven strategy}

Based mainly in the market orientation literature, a market-driven strategy emphasizes customers (e.g., Kohli \& Jaworski, 1990), employees (e.g., Narver \& Slater, 1990), and supplier relationships (e.g., Day, 1994; Matsuno \& Mentzer, 2000) and places relatively less emphasis on other stakeholders (e.g., shareholders, regulators, and communities). As discussed extensively in the market orientation literature, customers are central to market-driven firms. For instance, Narver and Slater (1990) identify customer orientation as an essential behavioral component of a market orientation, while Deshpande, Farley, and Webster (1993) argue that a customer orientation is, in some way, synonymous with a market orientation. Further, Webster (1992) views customer relationships as the firm's key strategic resource. As such, firms that put their customers' interests first achieve superior performance (Deshpande et al., 1993). This entails a sufficient understanding of the firm’s current and potential customers (Narver \& Slater, 1990), which can be obtained through the generation and dissemination of market intelligence across the different units within a firm (Kohli \& Jaworski, 1990). Those firms that invest substantial resources in understanding their customers and that coordinate the marketing actions in all the functions of the firm attain a competitive advantage (Slater \& Narver, 1994). 
The second type of relationship that firms which adopt a market-driven strategy focus on is employees. The importance of employee relationships is captured in the inter-functional coordination component of Narver and Slater's (1990) framework of market orientation. Specifically, firms must draw upon and effectively integrate their human resources to be able to create superior value for their customers. This requires the marketing function to be sensitive and responsive to the needs of the other units and functions within the firm. Another reason firms nurture employee relationships is because of the direct impact satisfied employees can have on performance outcomes, such as on the level of customer satisfaction (Homburg \& Stock, 2004). Market-driven firms also concentrate on supplier relationships when formulating and implementing marketing strategies. The inclusion of a supplier focus in market-driven strategy is rooted in Day (1994), who suggests that market-driven firms seek "closer, more collaborative relationships with suppliers based on a high level of coordination, participation in joint programs, and close communication links” (Day, 1994, pp. 44-45). Matsuno and Mentzer (2000) and Matsuno, Mentzer, and Rentz (2000) provide a further rationale that market-driven strategy is exemplified by firms that are cognizant of their suppliers' needs. Specifically, Matsuno et al. (2000) expand Kohli, Jaworski, and Kumar's (1993) market orientation scale (MARKOR) to incorporate suppliers into assessments of intelligence generation (e.g., whether the firm spends time with its suppliers to learn about their business), intelligence dissemination (e.g., whether the firm has cross-functional meetings regularly to discuss market developments regarding suppliers), and responsiveness (e.g., whether the firm is slow to start new business with new suppliers). In essence, supplier relationships can be instrumental to the firm's ability to achieve its marketdriven objectives (Buchanan, 1992). For instance, suppliers can help drive down a firm’s cost 
structure (Cannon \& Homburg, 2001), and interactions between the firm and its suppliers can lead to both incremental and radical innovations (Roy, Sivakumar, \& Wilkinson, 2004).

A market-driven strategy focuses more on a limited set of stakeholders that are directly related to marketing decisions, financial outcomes, and customer satisfaction (Kumar \& Reinartz, 2016). As such, the aim that firms with a market-driven strategy have is to satisfy customers' needs using good products/services with competitive prices, which intuitively contributes to better customer relationships and firm performance. However, compared to a stakeholder and sustainability focus, this strategy is less concerned with the social responsibility interface and more reactive than proactive in addressing social and environmental issues from a public policy perspective.

\subsubsection{Sustainability-centered strategy}

Sustainability-centered strategies are focused on achieving sustainable development by adhering to the philosophy of the "triple bottom line” - economic, environmental, and social performance (e.g., Chabowski, Mena, \& Gonzalez-Padron, 2011). As an example, Toyota has long embraced sustainability by experimenting with fuel technologies that not only meet but also raise industry standards (Toyota, 2017); by actively supporting recycling efforts; by participating in the hybrid/electric vehicle initiative; and by supporting education (Toyota, 2016). Brand equity can have many sources of support, including both internal and external support for a sustainabilitycentered strategy. These initiatives helped Toyota secure a good reputation, which in turn provided the company with a competitive edge, such as an increase in brand value (Kiley, 2007).

Adherence to the triple bottom line entails simultaneously and equally addressing the demands of shareholders (i.e., economic performance), regulators (i.e., environmental performance), and the community (i.e., social performance) when developing and executing 
strategies. With respect to economic performance, the primary interest of shareholders is to increase their returns (Day \& Fahey, 1988; Rao \& Bharadwaj, 2008). Firms that focus on enhancing shareholder value implement strategies that bring financial benefits exceeding the costs incurred (Day \& Fahey, 1988; Srivastava, Shervani, \& Fahey, 1998). This ensures the continuing operations of the firm, which also has a positive impact on the firm’s external economic environment, for instance, by providing employment (cf. Hart, 1997).

Firms adopting a sustainability-centered strategy also attend to regulators, given their influence on the firm's environment. For instance, several studies provide empirical evidence that regulatory forces lead to the integration of environmental issues into the firm's strategic plans (e.g., Banerjee, Iyer, \& Kashyap, 2003). Henriques and Sadorsky (1996) find that among different stakeholders, regulators have the greatest impact on a firm's likelihood to implement an environmental plan. This focus on regulators and regulations helps firms introduce better environmental practices and enhances their competitiveness (Buysse \& Verbeke, 2003; Porter \& van der Linde, 1995). In fact, environmental regulations can foster innovation, reduction of product costs, and continuous improvement (Porter \& van der Linde, 1995).

Sustainability-centered strategy also focuses on the community, due to its potential impact on social performance. Community stakeholders include nongovernmental organizations, geographic communities, and special interest groups organized around a political or social cause (Kassinis \& Vafeas, 2006). These groups are particularly important given that they can influence public opinion in favor of or against a firm (Henriques \& Sadorsky, 1999). In this context, improved social performance results from allocating company resources to social areas such as support to local schools and housing initiatives for the disadvantaged (Waddock \& Graves, 1997). 
Social performance, in turn, may lead to a competitive advantage and superior economic performance (Brammer \& Millington, 2008; Waddock \& Graves, 1997).

Among all three dimensions of the sustainability-centered strategy, environmental performance and social performance especially influence a company's reputation and how customers perceive it when evaluating competing brands. For instance, thirty-six percent of surveyed customers showed interest in purchasing an environmental car (i.e., electric vehicles) in 2016, increasing by five percent compared to $2015 .^{2}$ This significantly growing interest in environmental cars demonstrates that customers value sustainable products and are more likely to build relationships with firms/brands that are sustainability-centered (Liu, Yan, \& Zhou, 2017). In turn, these companies outperform others who do not emphasize sustainability.

A sustainability-centered strategy embraces multiple stakeholders and is aligned with social responsibility. However, this approach is not as broad as a stakeholder approach because the main focus is on environmental issues as they link to economic and social issues. A sustainabilitycentered approach is mainly instrumental in that marketing strategies focus on specific outcomes related to financial performance and the social and environmental well-being of key stakeholders such as communities. A sustainability-centered strategy has a strong public policy dimension. Existing public policy has developed incentives for engaging in this strategy.

Building on the previous discussion of market-driven, stakeholder-focused, and sustainability-centered marketing strategies, it follows that firm performance varies across the three strategic types and that this variation in performance can be explained within an industry by the firm's strategic group membership (e.g., Short et al., 2007). As such, firm performance is

\footnotetext{
${ }^{2}$ https://consumerfed.org/press_release/new-data-shows-consumer-interest-electric-vehicles-growing/
} 
shaped, in part, by whether a firm develops and implements stakeholder-focused, market-driven, or sustainability-centered marketing strategies. Stated formally:

$\mathrm{H}_{1}$ : $\quad$ Firm performance within industries varies across each of the three strategic groups associated with the (a) market-driven approach, (b) stakeholder-focused approach, and (c) sustainability-centered approach.

\subsection{Relative effects of the three marketing strategies}

Stakeholder theory predicts that adopting a stakeholder-focused strategy is relatively more important for firm performance than either the market-driven or sustainability-centered approaches. A firm exemplifying a stakeholder-focused strategy seeks to satisfy the demands of all the primary stakeholders (Clarkson, 1995). As we have discussed before, this perspective of marketing strategy is more comprehensive in nature than both the market-driven and the sustainability-centered strategies. On the other hand, the market-driven and the sustainabilitycentered groups emphasize some stakeholders, while downplaying others. However, paying simultaneous attention to the legitimate interests of all the primary stakeholders has important implications for building a brand reputation (Hillman \& Keim, 2001) and firm performance (Donaldson \& Preston, 1995). More specifically, compared to a stakeholder-focused strategy, a market-driven strategy is less concerned with the social responsibility interface and more reactive in addressing social and environmental issues. On the other hand, a sustainability-centered approach is mainly instrumental in that marketing strategies focus on specific outcomes related to financial performance and the social and environmental well-being of key stakeholders such as communities. Logically, firms with a stakeholder-focused strategy can better communicate their core values and propositions pertaining to ethics and social responsibility with the customers and offer more valuable products/services as well. This is especially true in the current situation with customers paying attention to and valuing ethics and social responsibility more than ever. These 
customers perceive firms with a stakeholder-focused strategy as more favorable, resulting in enhanced customer-brand relationships and firm performance.

In addition, the intangible, socially complex resources that this stakeholder-focused strategy can create (Hillman \& Keim, 2001) constitute mobility barriers that are difficult to overcome (Harrison et al., 2010). In turn, these barriers can also explain why firms with a stakeholder-focused strategy persistently have superior firm performance than firms defined by the two other strategies (Porter, 1980). As such, according to stakeholder theory, defining marketing strategy based on stakeholders results in a greater effect on performance than strategies defined by market-driven or sustainability-centered approaches:

$\mathrm{H}_{2}$ : $\quad$ Firm performance within an industry varies across types of strategic groups, with the stakeholder-focused strategy effect being greater than either the market-driven or sustainability-centered strategy effects.

Beyond our overarching predictions in $\mathrm{H} 1$ and H2, we develop additional hypotheses centered on the stakeholder-focused strategy, as it is the broadest of the three strategy types and conjectured to impart the strongest impact on firm performance. Previous research has shown that tangible product and service firms have uniquely different characteristics that affect strategy (e.g., Berry, 1999), as do low/stable and high technology firms (e.g., Slater, Hult, \& Olson, 2007). As such, we expect the effect of a firm's stakeholder-focused strategy to vary according to these segmentation variables as well.

\subsection{Product vs. service firms and stakeholder-focused strategy}

Important differences exist between tangible products and services that impact firms’ strategies and the effectiveness of these strategies (e.g., Berry, 1999). Two distinctions of service firms are especially relevant in the context of this study. First, the production and consumption processes occur simultaneously in services (Zeithaml, Parasuraman, \& Berry, 1985). Since 
customers are present during the service delivery, every service encounter represents an opportunity for the firm to develop a relationship with customers (Bitner, 1995). Second, the intangibility of services makes it nearly impossible for customers to evaluate the service offerings prior to experiencing them (Berry, 1995). Hence, it is essential for service firms to build relationships that are based on trust by openly communicating with customers and by operating with high standards of conduct that surpass legality (Berry, 1995). Due to these characteristics, the "nature of service businesses is relationship based" - which is not necessarily the case for tangible product firms (Grönroos, 1995, p. 252).

Relatedly, the concept of relationship marketing is closely connected to services marketing and has relevance for marketing strategy making (e.g., Grönroos, 1994; Morgan \& Hunt, 1994). Relationship marketing refers to "all marketing activities directed toward establishing, developing, and maintaining relational exchanges” (Morgan \& Hunt, 1994). In a meta-analysis of the effectiveness of relationship marketing, Palmatier, Dant, Grewel, and Evans (2006) found that building and maintaining strong customer relationships is, in general, more effective for performance in services relative to products. Service-dominant (S-D) logic rests its foundation on working with external stakeholders to create value and social performance (Vargo \& Lusch, 2004). Similar to but more expansive than relationship marketing, stakeholder theory centers on the importance of developing and nurturing relationships with a variety of stakeholders including customers to achieve superior performance (e.g., Jones, 1995). Given that service firms inherently manage relationships with customers and other stakeholders to deliver their intangible offerings, it follows that these firms are more adept than tangible product firms in building and maintaining these relationships. This leads stakeholder-focused service firms to have a greater effect on performance than tangible product firms. Therefore, we predict that: 
$\mathrm{H}_{3}$ : Stakeholder-focused strategy is associated with greater explained variance in firm performance in service firms than in tangible product firms.

\subsection{Low/stable vs. high technology firms and stakeholder-focused strategy}

Developing and executing marketing strategies that respond to the demands of multiple stakeholders is not an easy task given that stakeholder demands are seldom congruent (e.g., Donaldson \& Preston, 1995). This is especially challenging for firms that operate in high technology industries where "time-to-market and timing are critical, the rate of technological change is rapid, and the nature of future competition and markets difficult to determine” (Teece, Pisano, \& Shuen, 1997, p. 515). Hence, high technology firms not only have to deal with the stakeholders' competing demands, but they have to do so within an environment characterized by a constant state of flux and uncertainty. As such, the effectiveness of high tech firms' stakeholderfocused strategies is affected by factors that reside outside of the firms' control. On the other hand, firms that compete in low/stable technology industries do not experience as much change in the environment. Therefore, they have more time and a greater opportunity to learn what their stakeholders expect, implement marketing strategies that address these expectations, evaluate how effective their strategies are, and make any necessary adjustments to their strategies to better satisfy the stakeholders. Their effective stakeholder-focused strategies help transfer the messages about their image and core values to customers more efficiently, thus altering customers’ perceptions and advancing customer relationships. We predict that:

$\mathrm{H}_{4}$ : $\quad$ Stakeholder-focused strategy is associated with greater explained variance in firm performance in low/stable tech firms than in high tech firms. 


\section{Method}

\subsection{Data collection}

The dataset to test the research hypotheses was developed by combining objective secondary data from the Kinder Lydenburg Domini Statistical Tool for Analyzing Trends in Social and Environmental Performance (KLD STATS) and Standard \& Poor's Compustat database for a span of four years $\left(t_{0}, t_{1}, t_{2}\right.$, and $\left.t_{3}\right)$. A lagged structure was adopted for the analysis to be able to make causal inferences. Strategic group traits for the market-driven, sustainability-centered, and stakeholder-focused approaches used data from $t_{0}$ and $t_{1}$, while firm performance was based on data from $t_{2}$ and $t_{3}$. Two control levels - the firm and industry levels - were included as dummy coded variables in the multilevel analysis (Short et al., 2007). Data from each two-year period were averaged to provide more stable measures than single year data (cf. Bahadir, Bharadwaj, \& Srivastava, 2008). Complete data from KLD and Compustat for all measures and years were obtained for $\mathrm{n}=1,716$ firms. Table 1 reports the sample sizes for the various segments and different levels (firm, strategic group, and industry levels).

\section{Insert Table 1 about here}

KLD is a dataset of firms rated by KLD Research and Analytics, Inc., a social investment firm, since 1991 (starting with 650 firms in 1991 and now including more than 3,000 firms). Often referred to as the KLD dataset, MSCI Global Socially Responsible Indices took over the KLD indices in 2010. Through their commercial database of corporate ratings, SOCRATES, KLD Research Analytics, Inc. provides ratings on over 90 indicators in seven major areas including community, corporate governance, diversity, employee relations, environment, human rights, and products. The indicators include both positive and negative ratings (strengths and concerns). The ratings are based on an integration of five sources: (1) direct communication with firms, (2) global 
research firms, (3) media, (4) public documents, and (5) government and NGO information. KLD has been used in a variety of studies in marketing (e.g., Sen \& Bhattacharya, 2001) and management (e.g., Berman et al., 1999; Hillman \& Keim, 2001; Waddock \& Graves, 1997).

Compustat includes fundamental financial and market information data on about 24,000 active and 10,000 inactive publicly held firms in the U.S. and Canada. The database provides thousands of income statement, balance sheet, statement of cash flows, and supplemental data items. Compustat has been used in numerous marketing studies to measure performance-related variables. For example, prior marketing studies have used Compustat variables in conjunction with studying brands in mergers and acquisitions (Bahadir et al., 2008), customer satisfaction (Luo \& Homburg, 2008), brand portfolio strategy (Morgan \& Rego, 2009), and innovation related to consumer-packaged goods (Sorescu \& Spanjol, 2008).

The firms in the overall sample averaged $\$ 14,705$ million in total assets (std dev $=92,988$ ), total liabilities of $\$ 12,026$ million (std dev = 86,338), net income of $\$ 327$ million (std dev = 1,930 ), and revenue of $\$ 5,179$ million (std $\operatorname{dev}=18,255$ ) for 2007 . The firms were distributed into broadly categorized industries: agriculture, forestry, and fisheries ( $n=4$, NAICS codes: 111-115); minerals ( $n=77$, NAICS codes: 211-213); construction ( $n=28$, NAICS codes: 233-235); manufacturing ( $\mathrm{n}=834$, NAICS codes: 311-339 and 511); transportation, communications, and utilities ( $\mathrm{n}=197$, NAICS codes: 221, 481-493, and 513); wholesale trade ( $\mathrm{n}=38$, NAICS codes: 421-422); retail trade ( $\mathrm{n}=167$, NAICS codes: 441-454); finance, insurance, and real estate ( $\mathrm{n}=490$, NAICS codes: 521-533); and service industries ( $n=309$, NAICS codes: 512, 514, and 541-814). The industry of public administration (NAICS codes: 921-928) had no firms with complete data. Given these industry sizes, we can detect a medium strategic group effect (i.e., a medium portion 
of variance in market performance will be explained by the strategic group; Ferguson \& Ketchen, 1999).

\subsection{Defining marketing strategies via strategic groups}

As theoretically justified earlier in the paper, the formation of strategic groups was based on three approaches: stakeholder-focused approach (involving customers, suppliers, employees, regulators, shareholders, and the community), market-driven approach (customers, suppliers, and employees), and sustainability-centered approach (regulators, shareholders, and the community). The measures to assess these dimensions were obtained from KLD STATS. We included a battery of formative measures used in several previous studies: 6 items for customers, 20 items for employees, 3 items for suppliers, 9 items for shareholders, 7 items for regulators, and 20 items for community based on theoretically defined properties. These items centered on issues such as "the company’s products have notable social benefits that are highly unusual or unique for its industry” (customers); "the company has outstanding employee benefits or other programs addressing work/life concerns, e.g., childcare, elder care, or flextime” (employees); "the company does at least $5 \%$ of its subcontracting, or otherwise has a demonstrably strong record on purchasing or contracting, with women- and/or minority-owned businesses” (suppliers); "the company owns between $20 \%$ and $50 \%$ of another company that KLD has cited as having an area of social strength, or is more than $20 \%$ owned by a firm that KLD has rated as having social strengths” (shareholders); “the company has shown markedly responsible leadership on public policy issues and/or has an exceptional record of transparency and accountability concerning its political involvement in state or federal-level U.S. politics, or in non-U.S. politics” (regulators); and “the company has consistently given over $1.5 \%$ of trailing three-year net earnings before taxes to charity, or has otherwise been notably generous in its giving” (community). 
The scores for each dimension were adjusted based on the number of items to standardize the effects (cf. Graves \& Waddock, 1994). For each dimension, we calculated a total score by adding KLD items that were labeled as strengths and subtracting those labeled concerns. The average scores ranged from -.86 to .92 for community $(\bar{x}=-.00),-2.00$ to 1.00 for suppliers $(\bar{x}=-$ .07 ), -1.60 to .00 for regulators ( $\bar{x}=-.08$ ), -1.00 to 1.00 for employees $(\bar{x}=-.10),-2.00$ to 1.00 for customers $(\bar{x}=-.12)$, and -1.33 to .50 for shareholders $(\bar{x}=-.13)$.

A two-stage clustering procedure was used to group firms into strategic groups within each industry. A two-stage procedure is valuable because it increases the validity of the final cluster solutions obtained for each of the approaches, i.e., market-driven, sustainability-centered, and stakeholder-focused approaches (e.g., Ketchen \& Shook, 1996). Specifically, we used hierarchical clustering (i.e., Ward's method) to determine the number of appropriate groups in each broad industry category as well as their cluster centroids. Following standard practice, we used the largest percentage change in the agglomeration coefficient to suggest the optimal number of strategic groups in each broad industry. The cluster centroids were then used as the starting point for a non-hierarchical clustering procedure (i.e., K-means). Criterion validity was assessed through MANOVA significance tests following the procedures recommended by Ketchen and Shook (1996). As expected, the F-tests from Wilks’s lambda, provided by the MANOVA, indicated significant differences in firm performance based on strategic group membership for all industries in the overall sample $(\mathrm{p}<.01)$.

\subsection{Controlling for firm and industry effects}

In the context of research on strategic groups, firm and industry levels have been shown to have an effect on firm performance (e.g., Short et al., 2007). As such, they are both included as control levels in this study to better understand the effects of the strategic group level. The firm 
level is modeled as level 1 in the hierarchical linear multilevel modeling and the industry level is modeled as level 3, with the strategic group level being level 2 (e.g., Short et al., 2007). A number of theoretical reasons can be used to include the firm and industry levels, beyond controlling for their possible effects on performance. Theoretically, we find their inclusion primarily on the resource-based view (firm level) and industrial organization economics (industry level) in accordance with previous studies (e.g., Short et al., 2007).

The resource-based view of the firm (RBV) focuses on firm-level effects to explain longlived variation in performance outcomes across firms within the same industry (e.g., Peteraf, 1993). Specifically, it identifies the firm's idiosyncratic resources as the primary determinant of competitive advantage and firm performance (Barney, 1991). The RBV portrays resources as those tangible and intangible assets and capabilities possessed by a firm that enable the firm to implement valuable strategies that improve its efficiency and effectiveness (Barney, 1991; Wernerfelt, 1984). Firm resources include brand names, patents, corporate culture, trade contacts, knowledge, management skills, and efficient procedures (Barney, 1986, 1991; Grant, 1991; Wernerfelt, 1984). Several empirical studies have found the firm level to have substantial explanatory power in terms of performance (e.g., Mauri \& Michaels, 1998; Short et al., 2007). Regarding the industry level, industrial organization economics (IO) is perhaps the most dominant view used to explain the importance of industry effects (Bain, 1956; Mason, 1939). The structure-conduct-performance (SCP) paradigm within IO proposes that the structural elements of an industry influence the strategies (conduct) firms can pursue, which in turn determine their performance (Roquebert, Phillips, \& Westfall, 1996). As such, the industry is the main unit of analysis, and the industry structure in which the firm operates is seen as the primary determinant of firm performance (Hawawini, Subramanian, \& Verdin, 2003). Support for the notion that the 
industry in which the firm operates shapes the firm (Scott \& Davis, 2007) and in turn has an impact on its firm performance can be found in a number of studies. Specifically, previous research has examined the relative influence of firm and industry characteristics on firm performance by using various variance components models (e.g., McGahan \& Porter, 1997; Roquebert et al., 1996; Rumelt, 1991; Schmalensee, 1985). Although there is some discrepancy in the results with regards to the magnitude of the effects, these studies provide evidence that industry conditions influence firm profitability and should be controlled for when examining strategic group effects.

As depicted in Figure 1, the three levels are integrated with one another such that both the strategic group and the industry to which a firm is associated shape the firm, which in turn has an effect on the firm's performance. Our primary focus in this research is on level 2, the strategic group level, where we model the effects of a firm's market-driven, stakeholder-focused, and sustainability-centered strategies, respectively. To better understand the relative effects of a certain marketing strategy, with specific hypotheses for the stakeholder-focused approach, we also include segmentation variables.

\subsection{Inclusion of segmentation variables}

Figure 1 portrays two segmentation (moderating) variables in the multilevel framework. These include product vs. service firms and low/stable vs. high technology firms, which are used to examine the relationships in Hypotheses 3 and 4. Specifically, the product-focused firms are those in agriculture, forestry, and fisheries ( $n=4$, NAICS codes: 111-115); minerals ( $n=77$, NAICS codes: 211-213); construction ( $\mathrm{n}=28$, NAICS codes: $233-235)$; and manufacturing ( $\mathrm{n}=834$, NAICS codes: 311-339 and 511). A total of $n=825$ firms are mainly focused on delivering products based on their industry classification. The service-focused firms are those in transportation, 
communications, and utilities ( $\mathrm{n}=197$, NAICS codes: 221, 481-493, and 513); wholesale trade ( $n=38$, NAICS codes: 421-422); retail trade ( $n=167$, NAICS codes: 441-454); finance, insurance, and real estate ( $n=490$, NAICS codes: 521-533); and service industries ( $n=309$, NAICS codes: 512, 514, and 541-814). A total of $\mathrm{n}=891$ firms are mainly focused on delivering services.

The identification of the low/stable vs. high technology firms is based on the American Electronics Association's (AeA, 2003) classification of high tech industries. Founded in 1943, AeA is the largest high-tech trade association in the U.S. Forty-nine industries, at the six-digit level of NAICS, adhere to AeA's core definition of what constitutes a high-tech industry: "an industry had to be a maker/creator of technology, whether it is in the form of products, communications, or services” (AeA, 2003, p. 4). These 49 industries fall into 16 industry categories: computer and peripheral equipment, communications equipment, consumer electronics, electronic components, semiconductors, defense electronics, measuring and control instruments, electromedical equipment, photonics, communications services, software publishers, computer systems design and related services, internet services, engineering services, R\&D testing labs, and computer training. A total of $n=317$ firms of $n=1,716$ total firms are classified as high technology firms. The firms in the remaining NAICS classifications are considered either low or stable technology firms $(\mathrm{n}=1,399)$.

\subsection{Measuring firm performance}

We focus on Tobin's Q as our firm performance measure. Of the myriad of performance measures used previously in multilevel studies, Tobin's Q has been the most common in a variety of marketing studies (e.g., Anderson, Fornell, \& Mazvancheryl, 2004; Lee \& Grewal, 2004; Luo \& Bhattacharya, 2006; Luo \& Donthu, 2006; Rao, Agarwal, \& Dahloff, 2004; Sorescu \& Spanjol, 2008). More importantly, Tobin’s Q centers on “market performance” and, as such, aligns more 
closely with marketing strategy making and marketing implementation than return measures which are often used in multilevel studies (e.g., ROA). Tobin's Q was developed by James Tobin (1978), a Nobel laureate in economics, based on the concept that the collective market value of all firms on the stock market should be equal to their replacement costs. The formula for Q includes "the sum of the market value of equity, the book value of debt, and deferred taxes divided by the book value of total assets minus intangible assets” (Thomas \& Waring, 1999, p. 739). The average Tobin's $\mathrm{Q}$ for $\mathrm{t}_{2}$ and $\mathrm{t}_{3}$ is 1.40 (with a range of .60 to 12.78 and std $\mathrm{dev}=.77$ ).

\subsection{Hierarchical linear modeling (HLM)}

Testing of the multilevel effects on Tobin's Q in the overall and segmented samples (i.e., product vs. service firms; low/stable vs. high tech firms) was done via hierarchical linear modeling (Raudenbush, Bryk, Cheong, \& Congdon, 2004). HLM is particularly appropriate for this study because of the hierarchical nature of the data (i.e., firms are nested in strategic groups which are nested in industries) and because it provides for simultaneous partitioning of the variancecovariance components (Bryk \& Raudenbush, 1992).

A three-level model was used to test the effects of firms (level-1) nested within strategic groups (level-2) nested within industries (level-3). The level-1 model corresponds to the Tobin's Q performance of each firm as a function of a strategic group mean and random error. Thus, performance $_{\mathrm{ijk}}=\pi_{0 \mathrm{jk}}+e_{\mathrm{ijk}}$, where performance $e_{\mathrm{ijk}}$ is the average performance for Tobin's $\mathrm{Q}$ of firm $i$ in strategic group $j$ and industry $k . \pi_{0 \mathrm{jk}}$ is the mean performance of strategic group $j$ in industry $k$. $e_{\mathrm{ijk}}$ is a random firm effect (the deviation of firm ijk's score from the strategic group mean). The

effects are assumed to be normally distributed with a zero mean and variance $\sigma^{2}$. The subscripts $i$, $j$, and $k$ designate firms, strategic groups, and industries with $i=1,2, \ldots, n_{\mathrm{jk}}$ firms within strategic group $j$ in industry $k ; j=1,2, \ldots, J_{k}$ strategic groups within industry $k$; and $k=1,2, \ldots, K$ industries. 
The level-2 (strategic group) and level-3 (industry) models follow a similar format to that of the level-1 model. As such, the level-2 model examines each of the strategic group’s means, $\pi_{0 \mathrm{jk}}$, as an outcome that varies randomly around the industry mean: $\pi_{0 \mathrm{jk}}=\beta_{00 \mathrm{k}}+r_{0 \mathrm{jk}}$, where $\beta_{00 \mathrm{k}}$ is the strategic group Tobin's Q mean in industry $k$. $r_{0 \mathrm{jk}}$ is a random strategic group effect (the deviation of strategic group $j k$ 's mean from the industry mean). Similar to the level- 1 assumptions, these effects are assumed to be normally distributed with a zero mean and variance $\tau_{\pi}$. The level-3 model corresponds to the variability among industries, with the industry mean $\left(\beta_{00 k}\right)$ varying randomly around a grand mean: $\beta_{00 \mathrm{k}}=\gamma_{000}+u_{00 \mathrm{k}}$, where $\gamma_{000}$ is the grand mean. $u_{00 \mathrm{k}}$ is the random industry effect (the deviation of industry $k$ 's mean from the grand mean). These effects are also assumed to be normally distributed and have a zero mean and variance $\tau_{\beta}$.

As in many HLM studies, our objective in analyzing the three-level model is to partition the total variance in performance $\mathrm{ijk}_{\mathrm{jk}}(\mathrm{i} . \mathrm{e} .$, Tobin's Q) into its components for the overall sample and the four segmented samples: among firms within strategic groups $(\sigma 2)$, among strategic groups within industries $(\tau \pi)$, and among industries $(\tau \beta)$. This variance component partitioning allows for the estimation of the variance that can be attributed to firms within strategic groups $[\sigma 2 /(\sigma 2+\tau \pi$ $+\tau \beta)]$, to strategic groups within industries $[\tau \pi /(\sigma 2+\tau \pi+\tau \beta)]$, and among industries $[\tau \beta /(\sigma 2+$ $\tau \pi+\tau \beta)]$. However, our main focus is placed on the strategic group level given the focus of the study, the corporate firm effects modeled, and the coarse-grained industry categorization employed. The hierarchical linear and nonlinear modeling software HLM 7.03 was used to conduct the analyses (Raudenbush et al., 2004). 


\section{Results}

Our clustering procedures resulted in an average of 1.89 groups per industry using the stakeholder-focused approach (range: 1-3 groups), 2.56 groups using the market-driven approach (range: 1-5 groups), and 2.33 groups using the sustainability-centered approach (range: 1-4 groups). As indicated earlier, Table 1 reports on the number of firms, strategic groups, and industries covered in each analysis. Table 2 summarizes variance components and percent of total variance that is explained by the firm, strategic group, and industry levels in the 15 HLM models for the overall, segmented samples (product vs. service firms and low/stable tech vs. high tech firms), and type of strategic group used (stakeholder-focused, market-driven, or sustainabilitycentered group). Initially, we report the results of the firm and industry levels, followed by the strategic group level, which is the main focus of the study.

\section{Insert Table 2 about here}

\subsection{Firm and industry effects on firm performance}

Our analysis revealed that the variance accounted for by the firm level on the firm performance varied from 89.23 to 96.21 percent across sample types $(\mathrm{p}<.05)$. The variances accounted for in the overall analyses were all at the low end of the 90 percent range: 91.34 percent for stakeholder-focused, 91.97 percent for market-driven, and 92.25 percent for sustainabilitycentered. Regarding the product vs. service segments, the firm level explained a greater amount of the variance in Tobin's Q in all three models for the service firms (ranging from 93.32 to 94.04 percent) than in the tangible product firms (ranging from 89.23 to 90.03 percent). Similarly, in the low/stable tech vs. high tech analyses, we found that the firm level explained a greater amount of the variance in each of the high tech models (ranging from 95.46 to 96.21 percent) compared with the low/stable tech firms (ranging from 91.18 to 92.42 percent). The variances that are attributed 
to the firm level compare to other multilevel studies involving the firm level (e.g., McGahan \& Porter, 1997; Rumelt, 1991) and are consistent with the high firm-level variances using Tobin’s Q as the performance variable (Short et al., 2007).

In addition, the variance accounted for by the industry level of analysis varied from .72 to 9.42 percent across all samples. Eleven of the 15 samples had the industry level significant at $\mathrm{p}<.05$, one was significant at $\mathrm{p}<.10$ (low/stable tech firms using stakeholder-focused strategic groups), and three samples had non-significant industry levels (service firms using stakeholderfocused groups, high tech firms using stakeholder-focused groups, and high-tech firms using sustainability-centered groups). Regarding the product vs. service segments, the industry level explained a greater amount of the variance in firm performance in all three models for the tangible product firms (ranging from 8.00 to 9.42 percent) compared with the service firms (ranging from 1.74 to 5.00 percent). Similarly, in the low/stable tech vs. high tech analyses, we found that the industry level explained a greater amount of the variance in each of the low/stable tech models (ranging from 2.60 to 6.36 percent) compared with the high-tech firms (ranging from .72 to 4.27 percent).

\subsection{Marketing strategy effects on firm performance}

A number of interesting results were identified for the strategic group level that incorporated the market-driven, sustainability-centered, and stakeholder-focused strategies, respectively. The variances accounted for by the strategic group level ranged from .01 to 6.22 percent across all segments and strategy types. The group level was significant for the stakeholderfocused, market-driven, and sustainability-centered models in the overall analyses. The stakeholder-focused strategy achieved a variance of 5.58 percent compared with 1.77 percent for market-driven strategy and 1.42 percent for sustainability-centered strategy $(\mathrm{p}<.05)$. Thus, these 
results support Hypothesis 1 as well as Hypothesis 2, which posits that the stakeholder-focused strategy effect is greater than either the market-driven or sustainability-centered strategy effects.

When we delved deeper into the complexities of the analyses and results, we found that the results and significance levels varied in the segmented samples. For the models involving the stakeholder-focused strategy, the group level was significant at the $\mathrm{p}<.05$ level in three of the models, at the $\mathrm{p}<.10$ in one model (tangible product firms), and insignificant among high tech firms. For the market-driven strategy analyses, the group level was significant at the $\mathrm{p}<.05$ level in three of the models, at the $\mathrm{p}<.10$ level in one model (service firms), and insignificant among high tech firms. For the sustainability-centered strategy analyses, two of the models were significant at $\mathrm{p}<.05$, one at $\mathrm{p}<.10$ (low tech firms) and two insignificant (service firms and high tech firms).

The variance accounted for by the strategic group level which was defined based on a stakeholder-focused approach ranged from .78 percent among tangible product firms to 6.22 percent for low/stable tech firms. In the case of market-driven strategy, the range started at .01 percent in the high tech sample and peaked at 2.06 percent in the low/stable tech sample. For the groups defined based on the sustainability-centered approach, the range of the strategic group effect was .96 for service firms to 3.38 percent for high tech firms.

An interesting finding was that the strategic group level explained less variance than the firm and industry levels in 10 of the 15 models. However, four of the five models where the group level outperformed the industry level occurred for the stakeholder-focused strategy (the exception was among tangible product firms). In three of the five cases (overall sample, service firms, and low/stable tech firms), the stakeholder strategy outperformed groups defined by the market-driven and sustainability-centered approaches, lending additional credence to firms developing their strategy based on a stakeholder-focused approach (i.e., Hypothesis 2). 
In analyzing the segmented samples, we found that the stakeholder-focused strategy has a larger effect among service firms (4.94 percent) than it does among tangible product firms (.78 percent). In addition, the stakeholder strategy effect is larger among low/stable tech firms (6.22 percent) than it is for high tech firms (3.07 percent). These results provide support for Hypotheses 3 and 4. Furthermore, these effects in the service and low/stable tech samples also drive the results in the overall sample. The stakeholder-focused strategy effect in the overall sample (5.58 percent) outperformed the industry-level effect (3.08 percent).

\section{Discussion}

The primary focus of this study is to examine the relative value of firms adopting one of three different marketing strategies to achieve customer-brand relationships resulting in firm performance. The traditional view of marketing strategy, especially as rooted within a market orientation perspective, is captured within a marketing strategy labeled the market-driven approach. Ethics and social responsibility foundations stemming from a stakeholder-focused approach and a sustainability-centered approach are also included. In this research, our primary argument is that when firms develop and implement different types of marketing strategy, the corresponding brand communications, images, and core values, and more importantly products/services they are able to offer shape customers' perceptions of and experience with the firms/brands. Thus, customers' connections with firms using various marketing strategies are different, leading to variations in firm performance.

Overall, the results reveal that placing more emphasis on a broad set of stakeholders (i.e., customers, employees, suppliers, shareholders, communities, and regulators) by devoting attention and resources to addressing their simultaneous interests when developing marketing strategy is 
relatively more important for building a superior customer-brand relationship than is engaging in more limited market-driven or sustainability-centered efforts. This finding holds across service and low/stable technology firms. For tangible product firms, a sustainability-centered approach to marketing strategy making is more effective for firms to achieve better firm performance. These findings and the more intricate and fine-grained results have a number of managerial and public policy implications.

Many firms today formulate and implement marketing strategies in accordance with multiple stakeholders and/or a triple bottom line focus on sustainability issues (cf. Handelman \& Arnold, 1999). An important contribution of this study is that it is the first to demonstrate that, in general, developing a marketing strategy based on a stakeholder-focused approach (i.e., taking into consideration the needs and interests of the six primary stakeholders) is more effective than strategy making based on market-driven or sustainability-centered approaches. While we take an instrumental approach, the implications for a normative stakeholder focus based on values is strong. Also, as an empirical research that aims to provide abundant managerial implications, the instrumental approach seems to fit more in our context (Donaldson \& Preston, 1995). Specifically, our research suggests that firms that are "stewards for a better society," and thereby attend to the demands of a broad set of stakeholders when developing marketing strategies (Laczniak \& Murphy, 2012), are rewarded from a firm performance standpoint. As stated, this firm performance may be associated with social responsibility that enhances customer relationships and satisfaction (Luo \& Bhattacharya, 2006). Also, ethicality of the brand can relate to a stakeholderfocused strategy, and the positive relationship between ethicality of a brand and both brand trust and brand effect, can result in increasing brand sales and performance (Singh, Iglesias, \& BatistaFoguet, 2012). As such, this study provides confidence and encouragement to executives to 
accommodate the needs of a broader set of stakeholders when they develop and implement marketing strategies. In addition, this research is able to respond to the calls that more investigations are in need to determine relationships between brand ethicality and brand preferences and loyalty, given that more and more consumers possess strong motivations for “ethical” consumption associated with social responsibility (Davies \& Gutsche, 2016).

In the overall results, the stakeholder-focused approach accounted for approximately 6 percent of the variance compared with about 2 and 1 percent, respectively, for the market-driven and sustainability-centered approaches. Brush and Bromiley (1997) pointed out that when interpreting variance components, their relative importance can be examined via the square root of the variance at each level of analysis. In terms of firm performance (Tobin’s Q), the relative importance of the market-driven approach (9.90 percent) and sustainability-centered approach (8.94 percent) is roughly half as important as the industry (18.65 percent for the industry in the market-driven sample and 18.91 percent for the industry in the sustainability-centered sample) in which the firm operates in the sample of all firms (see Table 3). However, using the stakeholderfocused approach, the relative importance of the strategic group level is about 1.5 times that of the industry (17.28 percent for the group level vs. 12.83 percent for the industry level). This relative importance holds consistently for stakeholder-focused firms when analyzing service-focused firms, low/stable technology firms, and high technology firms (the only exception is tangible product firms). These three approaches' relative importance reinforces that firms ought to consider all primary stakeholders' demands and cope with them effectively rather than stressing profit maximization.

\section{Insert Table 3 about here}


Our results also suggest that catering to the needs of multiple stakeholders is especially important for service and low/stable technology firms. In other words, these firms are better off developing a marketing strategy based on a stakeholder-focused approach. The justifications for such a suggestion are that it seems that since service firms are inherently relationship based (e.g., Grönroos, 1995), they are more proficient than tangible product firms in developing and maintaining strong stakeholder relationships. Similarly, low/stable technology firms are more effective at translating stakeholder-focused efforts into firm performance, in that the more stable environment affords these firms a better opportunity to learn what their primary stakeholders demand and to implement strategies to meet such demands. These better outcomes of implementing a stakeholder-focused strategy can be communicated to customers in a more effective way, which shapes customers' perceptions of firms favorably and enhances customerbrand relationships and firm performance ultimately. It is also possible that low/stable technology firms have more brand visibility than high technology firms, and therefore, have more consumer awareness about their business ethics and social responsibility.

While our findings support the superiority of developing marketing strategies that meet the needs of multiple stakeholders, this is not always the case. For tangible product firms, developing a marketing strategy by adopting a sustainability-centered approach to doing business is more effective. This result is counterintuitive as it implies that the interests of the customers, suppliers, and employees - crucial stakeholder groups - are not as important as the claims of the shareholders, regulators, and communities. On the other hand, due to the nature of a tangible product, these firms have a more visible opportunity for incorporating sustainability into social responsibility initiatives that impact these key stakeholders, including customers' perceptions of the firms/brands. Social responsibility from a stakeholder perspective includes social issues, 
employee well-being, legal responsibilities, philanthropy, consumer protection, and corporate governance as well as sustainability (Ferrell et al., 2017). Sustainability is usually the most visible social responsibility issue for tangible products, which possibly explains our results.

\section{Conclusions}

While market-driven strategies have been linked to superior firm performance, sustainability-centered and stakeholder-focused strategies have emerged as alternative marketing performance linkages. These different marketing strategy approaches shape brand images and value propositions that affect firm performance. Consumers experience the strategies through their interaction with and awareness of the brand. These strategy approaches can be benchmarked for ethical, social, and economic performance driven by these customer-brand relationships. This study, using secondary data, finds that placing more emphasis on a broad set of stakeholders when developing marketing strategy is most important in achieving superior performance. While there are exceptions, such as tangible product firms that are more effective using a sustainabilitycentered approach, in all cases either a stakeholder approach or a sustainability-centered approach is superior in improving customer-brand relationships and performance. There can possibly be an integration of these two approaches while still maintaining a market orientation (Crittenden et al., 2011). A call for strategic change is found in research which indicates that companies that change strategies regularly outperform companies that change strategies irregularly (Klarner \& Raisch, 2013).

These findings have implications for marketing and public policy. While Laczniak and Murphy (2012) view that marketers are primarily pragmatic and firm-centric, they call for normative and aspirational ethical standards, more consideration of social responsibility issues, 
and greater engagement with external stakeholder networks. Our findings provide encouragement that there are strengths in focusing on external stakeholders and a strong linkage to favorable brand images in consumers' mind and eventually superior performance. The opportunity exists to provide market-driven approaches as a major part of the "social contract" that firms have with their stakeholders. The other is the social responsibility to engage stakeholders, creating a societalgrounded license for economic profit (Laczniak \& Murphy, 2012). According to Wilkie and Moore (2011), scientific, managerial, and micro-level theoretical perspectives have continued to dominate marketing. In the last 5 years, the Journal of Business Research has published 12 market orientation, 10 sustainability, 18 stakeholder, and 40 social responsibility (CSR) titled articles. This is a strong indication that social responsibility and stakeholder research is gaining traction. The articles with social responsibility and stakeholder publications more than double the number published with market orientation and sustainability in the title. This indicates that there is increasing knowledge about the linkage of social responsibility and stakeholder-focused approach to strategy. A stakeholder focus can address the concerns of social issues and consumer protection as they relate to various constituents. The linkage of stakeholder concerns with superior performance is a win-win solution for the common good and social responsibility. Further evidence to support this approach is Ethisphere's findings that the World's Most Ethical companies outperformed the U.S. large CAP index by 6.67\% in 2017 (Ethisphere, 2018).

Serving as a starting point, this research calls for further investigation into how a firm's relationships with its primary stakeholders affect customer-brand relationship and are shaped by ethical and socially responsible touch points. Theoretically, these primary stakeholders include customers, employees, suppliers, shareholders, communities, and regulators. Another important avenue for future research centers on the influence of secondary stakeholders, such as the media 
and special interest groups, that are not vital for the firm's survival but can still mobilize public opinion in favor of or against a firm (Clarkson, 1995). We conjecture that they may also have a profound impact on customer-brand relationship given their influence on the public. While this study uses firm-based secondary data, there is a need for more consumer research related to ethical and sustainable consumption (Sudbury-Riley \& Kohlbacher, 2016). In addition, direct examinations on the relationship of sustainability-centered and stakeholder-focused strategies to customer brand attitude could provide more insights related to firm performance. Also, given our results on the relationship between a sustainability view and firm performance in tangible product firms, future research needs to delve deeper into our findings and to determine whether they hold across different contingencies and whether the three strategies can be used in any form of a combinative manner (e.g., Hult, 2011; Sheth et al., 2011) to drive firm performance.

In a general sense, this study answers calls for research that incorporates marketing strategy insights from an expanded view of marketing beyond its traditionally heavy emphasis on customers (e.g., Bhattacharya, 2010; Hult et al., 2011; Maignan \& Ferrell, 2004; Smith et al., 2010). In addition, this research provides a foundation to explore customer-brand relationships that create enduring customer value and performance linkage (Kumar \& Reinartz, 2016). Finally, research is needed to assess how to prioritize and address the co-creation of value with various stakeholders. Additionally, how can public policy decision makers take knowledge about the benefits of a stakeholder and sustainability approach and provide rewards or incentives to firms that shift to these strategies? 


\section{References}

Abela, Andrew V. \& Murphy, P. E. (2008). Marketing with Integrity: Ethics and the ServiceDominant Logic for Marketing. Journal of the Academy of Marketing Science, 36, 39-53.

American Electronics Association (2003). Defining the High-Tech Industry, Washington, DC: American Electronics Association.

Anderson, Eugene W., Fornell, Claes, \& Mazvancheryl, Sanal K. (2004). Customer Satisfaction and Shareholder Value. Journal of Marketing, 68 (October), 172-185.

Bahadir, S. Cem, Bharadwaj, Sundar G., \& Srivastava, Rajendra K (2008). Financial Value of Brands in Mergers and Acquisitions: Is Value in the Eye of the Beholder? Journal of Marketing, 72 (November), 49-64.

Bain, J.S. (1956). Barriers to New Competition: Their Character and Consequences in Manufacturing Industries. Cambridge, MA: Harvard University Press.

Banerjee, Subhabrata Bobby, Iyer, Easwar S., \& Kashyap, Rajiv K. (2003). Corporate Environmentalism: Antecedents and Influence of Industry Type. Journal of Marketing, 67 (April), 106-122.

Barney, Jay B. (1986). Strategic Factor Markets: Expectations, Luck, and Business Strategy. Management Science, 32 (10), 1231-1241.

Barney, Jay B. (1991). Firm Resources and Sustained Competitive Advantage. Journal of Management, 17 (1), 99-120.

Barney, Jay B. \& Robert E. Hoskisson (1990). Strategic Groups: Untested Assertions and Research Proposals. Managerial and Decision Economics, 11 (3), 187-198.

Berman, Shawn L., Andrew C. Wicks, Suresh Kotha, \& Thomas M. Jones (1999). Does Stakeholder Orientation Matter? The Relationship between Stakeholder Management Models and Firm Financial Performance. Academy of Management Journal, 42 (5), 488-506.

Berry, Leonard L. (1995). Relationship Marketing of Services - Growing Interest, Emerging Perspectives. Journal of the Academy of Marketing Science, 23 (4), 236-245.

Berry, Leonard L. (1999). Discovering the Soul of Service: The Nine Drivers of Sustainable Business Success. New York, NY: The Free Press.

Bhattacharya, C.B. (2010). Introduction to the Special Section on Stakeholder Marketing. Journal of Public Policy \& Marketing, 29 (1), 1-3.

Bhattacharya, C.B. \& Daniel Korschun (2008). Stakeholder Marketing: Beyond the Four Ps and the Customer. Journal of Public Policy \& Marketing, 27 (1), 113-116

Bitner, Mary Jo (1995). Building Service Relationships: It's All about Promises. Journal of the Academy of Marketing Science, 23 (4), 246-251. 
Brammer, Stephen \& Andrew Millington (2008). Does it Pay to be Different? An Analysis of the Relationship between Corporate Social and Financial Performance. Strategic Management Journal, 29 (12), 1325-1343.

Brush, Thomas H. \& Philip Bromiley (1997). What Does a Small Corporate Effect Mean? A Variance Components Simulation of Corporate and Business Effects. Strategic Management Journal, 18 (10), 825-835.

Bryk, Anthony S. \& Stephen W. Raudenbush (1992). Hierarchical Linear Models: Applications and Data Analysis Methods. Newbury Park, CA: Sage Publications.

Buchanan, Lauranne (1992). Vertical Trade Relationships: The Role of Dependence and Symmetry in Attaining Organizational Goals. Journal of Marketing Research, 29 (1), 65-75.

Buysse, Kristel \& Alain Verbeke (2003). Proactive Environmental Strategies: A Stakeholder Management Perspective. Strategic Management Journal, 24 (5), 453-470.

Cannon, Joseph P. \& Christian Homburg (2001). Buyers-Supplier Relationships and Customer Firm Costs. Journal of Marketing, 65 (1), 29-43.

Castaldo, Sandro, Francesco Perrini, Nicola Misani, \& Antonio Tencati (2009). The Missing Link between Corporate Social Responsibility and Consumer Trust: The Case of Fair Trade Products. Journal of Business Ethics, 84 (1), 1-15.

Caves, R.E. \& M.E. Porter (1977). From Entry Barriers to Mobility Barriers: Conjectural Decisions and Contrived Deterrence to New Competition. Quarterly Journal of Economics, 91 (2), 241-262.

Chabowski, Brian R., Jeannette A. Mena, \& Tracy L. Gonzalez-Padron (2011). The Structure of Sustainability Research in Marketing, 1958-2008: A Basis for Future Research. Journal of the Academy of Marketing Science, 39 (February), 55-70.

Choi, Jaepil \& Heli Wang (2009). Stakeholder Relations and the Persistence of Corporate Financial Performance. Strategic Management Journal, 30 (8), 895-907.

Clarkson, Max (1995). A Stakeholder Framework for Analyzing and Evaluating Corporate Social Performance. Academy of Management Review, 20 (1), 92-117.

Colgate, Mark R. \& Peter J. Danaher (2000). Implementing A Customer Relationship Strategy: The Asymmetric Impact of Poor versus Excellent Execution. Journal of the Academy of Marketing Science, 28(3), 375-387.

Cool, Karel \& Ingemar Dierickx (1993). Rivalry, Strategic Groups and Firm Profitability. Strategic Management Journal, 14 (1), 47-59.

Crittenden, Victoria L., William F. Crittenden, Linda K. Ferrell, O. C. Ferrell, \& Christopher C. Pinney (2011). Market-Oriented Sustainability: A Conceptual Framework and Propositions. Journal of the Academy of Marketing Science, 39 (February), 71-85. 
Daub, Claus-Heinrich \& Rudolf Ergenzinger (2005). Enabling Sustainable Management through a New Multi-Disciplinary Concept of Customer Satisfaction. European Journal of Marketing, 39 (9/10), 998-1012.

Davies, Andrews \& Sabrina Gutsche (2016). Consumer motivations for mainstream “ethical” consumption. European Journal of Marketing, 50(7), 1326-1347.

Day, George S. (1994). The Capabilities of Market-Driven Organizations. Journal of Marketing, 58 (4), 37-52.

Day, George \& Liam Fahey (1988). Valuing Market Strategies. Journal of Marketing, 52 (3), 4557.

Deshpande, Rohit, John U. Farley, \& Frederick E. Webster, Jr. (1993). Corporate Culture, Customer Orientation, and Innovativeness in Japanese Firms: A Quadrad Analysis. Journal of Marketing, 57 (1), 23-37.

Donaldson, Thomas \& Lee E. Preston (1995). The Stakeholder Theory of the Corporation: Concepts, Evidence, and Implications. Academy of Management Review, 20 (1), 65-91.

Ferguson, Tamela D. \& David J. Ketchen, Jr. (1999). Organizational Configurations and Performance: The Role of Statistical Power in Extant Research. Strategic Management Journal, 20 (4), 385-395.

Fernandez, Leslier M.V. \& Francisco Pinuer (2016). Influence of Customer Value Orientation, Brand Value, and Business Ethics Level on Organizational Performance. Review of Business Management, 18 (59), 5-23.

Ferrell, O.C., Tracy L. Gonzalez-Padron, G. Tomas M. Hult, \& Isabelle Maignan (2010). From Market Orientation to Stakeholder Orientation. Journal of Public Policy \& Marketing, 29 (1), 9396.

Ferrell, O.C., John Fraedrich, \& Linda Ferrell (2017). Business Ethics: Ethical Decision Making and Cases, Boston, MA: Cengage Learning.

Fiegenbaum, Avi \& Howard Thomas (1990). Strategic Groups and Performance: The U.S. Insurance Industry, 1970-84. Strategic Management Journal, 11 (3), 197-215.

Fiegenbaum, Avi \& Howard Thomas (1995). Strategic Groups as Reference Groups: Theory, Modeling and Empirical Examination of Industry and Competitive Strategy. Strategic Management Journal, 16 (6), 461-476.

Freeman, R. Edward (1984). Strategic Management: A Stakeholder Approach. Marshfield, MA: Pitman Publishing Inc.

Freeman, R. Edward \& L. Stewart (2006). Developing Ethical Leadership. Business Roundtable Institute for Corporate Ethics, www.corporate-ethics.org.

Frooman, Jeff (1999). Stakeholder Influence Strategies. Academy of Management Review, 24 (2), 191-205. 
Frow, Pennie \& Adrian Payne (2011). A Stakeholder Perspective of the Value-Proposition Concept. European Journal of Marketing, 45 (1-2), 223-240.

Good Ethics is Good Business, Ethisphere, https://www.worldsmostethicalcompanies.com, accessed Jan 9, 2018.

Grant, Robert M. (1991). The Resource-Based Theory of Competitive Advantage: Implications for Strategy Formulation. California Management Review, 33 (3), 114-135.

Graves, Samuel B. \& Sandra A. Waddock (1994). Institutional Owners and Corporate Social Performance. Academy of Management Journal, 37 (4), 1034-1046.

Greenley, Gordon E. \& Gordon R. Foxall (1998). External Moderation of Associations among Stakeholder Orientations and Company Performance. International Journal of Research in Marketing, 15 (1), 51-69.

Grönroos, Christian (1994). From Marketing Mix to Relationship Marketing: Towards a Paradigm Shift in Marketing. Management Decision, 32 (2), 4-20.

Grönroos, Christian (1995). Relationship Marketing: The Strategy Continuum. Journal of the Academy of Marketing Science, 23 (4), 252-254.

Handelman, Jay M. \& Stephen J. Arnold (1999). The Role of Marketing Actions with a Social Dimension: Appeals to the Institutional Environment. Journal of Marketing, 63 (3), 33-48.

Harrison, Jeffrey S., Douglas A. Bosse, \& Robert A. Phillips (2010). Managing for Stakeholders, Stakeholder Utility Functions, and Competitive Advantage. Strategic Management Journal, 31 (1), 58-74.

Hart, Stuart L. (1995). A Natural-Resource-Based View of the Firm. Academy of Management Review, 20 (4), 986-1014.

Hart, Stuart L. (1997). Beyond Greening: Strategies for a Sustainable World. Harvard Business Review, 75 (1), 66-76.

Hatten, Kenneth J. \& Mary Louise Hatten (1987). Strategic Groups, Asymmetrical Mobility Barriers and Contestability. Strategic Management Journal, 8 (4), 329-342.

Hawawini, Gabriel, Venkat Subramanian, \& Paul Verdin (2003). Is Performance Driven By Industry- or Firm-Specific Factors? A New Look at the Evidence. Strategic Management Journal, 24 (1), 1-16.

Henriques, Irene \& Perry Sadorsky (1996). The Determinants of an Environmentally Responsive Firm: An Empirical Approach. Journal of Environmental Economics and Management, 30(3), 381-395.

Henriques, Irene \& Perry Sadorsky (1999). The Relationship between Environmental Commitment and Managerial Perceptions of Stakeholder Importance. Academy of Management Journal, 42(1), 87-99.

Hillman, Amy J. \& Gerald D. Keim (2001). Shareholder Value, Stakeholder Management, and Social Issues: What's the Bottom Line? Strategic Management Journal, 22 (2), 125-139. 
Homburg, Christian \& Ruth M. Stock (2004). The Link between Salespeople's Job Satisfaction and Customer Satisfaction in a Business-to-Business Context: A Dyadic Analysis. Journal of Marketing, 32(2), 144-158.

Huang, Ming-Hui \& Roland T. Rust (2011). Sustainability and Consumption. Journal of the Academy of Marketing Science, 39(1), 40-54.

Huang, Zhi, Hong Susan Zhu, \& Daniel J. Brass (2017). Cross-border acquisitions and the asymmetric effect of power distance value difference on long-term post-acquisition performance. Strategic Management Journal, 38 (4), 972-991.

Huber, F., K. Vollhardt, I. Matthes, \& J. Vogel (2010). Brand misconduct: Consequences on consumer-brand relationships. Journal of Business Research, 63(11), 1113-1120.

Hult, G. Tomas M. (2011). Market-Focused Sustainability: Market Orientation Plus! Journal of the Academy of Marketing Science, 39 (1), 1-6.

Hult, G. Tomas M., Jeannette A. Mena, O. C. Ferrell, \& Linda Ferrell (2011). Stakeholder Marketing: A Definition and Conceptual Framework. AMS Review, 1 (1), 44-65.

Hunt, Shelby D. (2011). Sustainable Marketing, Equity, and Economic Growth: A ResourceAdvantage, Economic Freedom Approach. Journal of the Academy of Marketing Science, 39 (1), 7-20.

Jaworski, Bernard J. \& Ajay K. Kohli (1993). Market Orientation: Antecedents and Consequences. Journal of Marketing, 57 (3), 53-70.

Jones, Thomas M. (1995). Instrumental Stakeholder Theory: A Synthesis of Ethics and Economics. Academy of Management Review, 20 (2), 404-437.

Kassinis, George \& Nikos Vafeas (2006). Stakeholder Pressures and Environmental Performance. Academy of Management Journal, 49 (1), 145-159.

Ketchen, David J. \& Christopher L. Shook (1996). The Application of Cluster Analysis in Strategic Management Research: An Analysis and Critique. Strategic Management Journal, 17 (6), 441-458.

Kiley, David (2007). How the Hybrid Race Went to the Swift. BusinessWeek, (January 29), 58.

Kirca, Ahmet H., Satish Jayachandran, \& William O. Bearden (2005). Market Orientation: A Meta-Analytic Review and Assessment of Its Antecedents and Impact on Performance. Journal of Marketing, 69 (2), 24-41.

Klarner, Patricia \& Sebastian Raisch (2013). Move to the Beat-Rhythms of Change and Firm Performance. Academy of Management Journal, 56 (1), 160-184.

Kohli, Ajay K. \& Bernard J. Jaworski (1990). Market Orientation: The Construct, Research Propositions, and Managerial Implications. Journal of Marketing, 54 (2), 1-18.

Kohli, Ajay K., Bernard J. Jaworski, \& Ajith Kumar (1993). MARKOR: A Measure of Market Orientation. Journal of Marketing Research, 30 (4), 467-477. 
Kull, Alexander J., Jeannette A. Mena, \& Daniel Korschun (2016). A Resource-Based View of Stakeholder Marketing. Journal of Business Research, 69 (12), 5553-5560.

Kumar, V (2015). Evolution of marketing as a discipline: What has happened and what to look out for. Journal of Marketing, 79 (1), 1-9.

Kumar, V. \& W. Reinartz (2016). Creating enduring customer value. Journal of Marketing, 80, 36-68.

Laczniak, Gene R. \& Patrick E. Murphy (2012). Stakeholder Theory and Marketing: Moving from a Firm-Centric to a Societal Perspective. Journal of Public Policy \& Marketing, 31 (2), 284-292.

Lee, Ruby \& Rajdeep Grewal (2004). Strategic Responses to New Technologies and Their Impact on Firm Performance. Journal of Marketing, 68 (October), 1578-171.

Lewis, Pam \& Howard Thomas (1990). The Linkage between Strategy, Strategic Groups, and Performance in the U.K. Retail Grocery Industry. Strategic Management Journal, 11 (5), 385-397.

Liu, Qing, Zhen Yan, \& Jiehong Zhou (2017). Consumer choices and motives for eco-Labeled products in China: An empirical analysis based on the choice experiment. Sustainability, 9 (3), 331.

Luo, Xueming \& C. B. Bhattacharya (2006). Corporate Social Responsibility, Customer Satisfaction, and Market Value. Journal of Marketing, 70 (4), 1-18.

Luo, Xueming \& Christian Homburg (2008). Satisfaction, Complaint, and the Stock Value Gap. Journal of Marketing, 72 (July), 29-43.

Luo, Xueming \& Naveen Donthu (2006). Marketing’s Credibility: A Longitudinal Investigation of Marketing Communication Productivity and Shareholder Value. Journal of Marketing, 70 (October), 70-91.

Lusch, Robert F. \& Frederick E. Webster Jr. (2011). A Stakeholder-Unifying, Cocreation Philosophy for Marketing. Journal of Macromarketing, 31 (2), 129-134

Maignan, Isabelle \& O. C. Ferrell (2004). Corporate Social Responsibility and Marketing: An Integrative Framework. Journal of the Academy of Marketing Science, 32 (1), 3-19.

Maignan, Isabelle, Tracy L. Gonzalez-Padron, G. Tomas M. Hult, \& O.C. Ferrell (2011). Stakeholder Orientation: Development and Testing of a Framework for Socially Responsible Marketing. Journal of Strategic Marketing, 19 (4), 353-378.

Maio, Elsie (2003). Managing Brand in the New Stakeholder Environment. Journal of Business Ethics, 44: 235-246.

Mason, Edward S. (1939). Price and Production Policies of Large-Scale Enterprises. American Economic Review, 29 (1), 61-74.

Matsuno, Ken \& John T. Mentzer (2000). The Effects of Strategy Type on the Market Orientation - Performance Relationship. Journal of Marketing, 64 (4), 1-16. 
Matsuno, Ken, John T. Mentzer, \& Joseph O. Rentz (2000). A Refinement and Validation of the MARKOR Scale. Journal of the Academy of Marketing Science, 28 (4), 527-539.

Mauri, Alfredo J. \& Max P. Michaels (1998). Firm and Industry Effects within Strategic Management: An Empirical Examination. Strategic Management Journal, 19 (3), 211-219.

McGahan, Anita A. \& Michael E. Porter (1997). How Much Does Industry Matter, Really? Strategic Management Journal, 18 (S1), 15-30.

McGee, John \& Howard Thomas (1986). Strategic Groups: Theory, Research, and Taxonomy. Strategic Management Journal, 7 (2), 141-160.

Mehra, Ajay (1996). Resource and Market Based Determinants of Performance in the U.S. Banking Industry. Strategic Management Journal, 17 (4), 307-322.

Mitchell, Ronald K., Bradley R. Agle, \& Donna J. Wood (1997). Toward a Theory of Stakeholder Identification and Salience: Defining the Principle of Who and What Really Counts. Academy of Management Review, 22 (4), 853-886.

Morgan, Neil A. \& Lopo L. Rego (2009). Brand Portfolio Strategy and Firm Performance. Journal of Marketing, 73 (January), 59-74.

Morgan, Robert M. \& Shelby D. Hunt (1994). The Commitment-Trust Theory of Relationship Marketing. Journal of Marketing, 58 (3), 20-38.

Nair, Anil \& Suresh Kotha (2001). Does Group Membership Matter? Evidence from the Japanese Steel Industry. Strategic Management Journal, 22 (3), 221-235.

Narver, John C. \& Stanley F. Slater (1990). The Effect of a Market Orientation on Business Profitability. Journal of Marketing, 54 (4), 20-35.

Palmatier, Robert W., Rajiv P. Dant, Dhruv Grewal, \& Kenneth R. Evans (2006). Factors Influencing the Effectiveness of Relationship Marketing: A Meta-Analysis. Journal of Marketing, 70 (4), 136-153.

Park, Eunil, Ki J. Kim, \& Sang Kwon (2017). Corporate social responsibility as a determinant of consumer loyalty: An examination of ethical standard, satisfaction, and trust. Journal of Business Research, 76(1), 8-13.

Peteraf, Margaret A. (1993). The Cornerstones of Competitive Advantage: A Resource-Based View. Strategic Management Journal, 14 (3), 179-191.

Pfeffer, Jeffrey \& Gerald R. Salancik (1978). The External Control of Organizations: A Resource Dependence Perspective. New York: Harper \& Row.

Porter, Michael E. (1979). The Structure within Industries and Companies’ Performance. The Review of Economics and Statistics, 61 (2), 214-227.

Porter, Michael E. (1980), Competitive Strategy: Techniques for Analyzing Industries and Competitors. New York: The Free Press. 
Porter, Michael R. \& Claas van der Linde (1995). Toward a New Conception of the EnvironmentCompetitiveness Relationship. Journal of Economic Perspectives, 9 (4), 97-118.

Prabu, David \& Susan Kline (2005). Corporate Social Responsibility Practices, Corporate Identity, and Purchase Intention: A Dual-Process Model. Journal of Public Relations Research, 17 (3), 291-313.

Rao, Ramesh K.S. \& Neeraj Bharadwaj (2008). Marketing Initiatives, Expected Cash Flows, and Shareholders' Wealth. Journal of Marketing, 72 (1), 16-26.

Rao, Vithala, Manoj K. Agarwal, \& Denise Dahloff (2004). How Is Manifest Branding Strategy Related to the Intangible Value of a Corporation? Journal of Marketing, 68 (October), 126-141.

Raudenbush, Stephen, Anthony Bryk, Yuk Fai Cheong, \& Richard Congdon (2004). HLM 6:

Hierarchical Linear \& Nonlinear Modeling. Lincolnwood, IL: SSI Scientific Software International.

Roquebert, Jaime A., Robert L. Phillips, \& Peter A. Westfall (1996). Markets vs. Management: What ‘Drives’ Profitability? Strategic Management Journal, 17 (8), 653-664.

Roy, Subroto, K. Sivakumar, \& Ian F. Wilkinson (2004). Innovation Generation in Supply Chain Relationships: A Conceptual Model and Research Propositions. Journal of the Academy of Marketing Science, 32 (1), 61-79.

Rubera, Gaia \& Ahmet H. Kirca (2017). You gotta serve somebody: the effects of firm innovation on customer satisfaction and firm value. Journal of the Academy of Marketing Science, 45 (5), 741-761.

Ruekert, Robert W. (1992). Developing a Market Orientation: An Organizational Strategy Perspective. International Journal of Research in Marketing, 9 (3), 225-245.

Rumelt, Richard P. (1991). How Much Does Industry Matter? Strategic Management Journal, 12 (3), 167-185.

Schmalensee, Richard (1985). Do Markets Differ Much? American Economic Review, 75 (June), 341-351.

Scott, W. Richard \& Gerald F. Davis (2007). Organizations and Organizing: Rational, Natural, and Open System Perspectives. Upper Saddle River, NJ: Pearson Prentice-Hall.

Sen, Sankar \& C.B. Bhattacharya (2001). Does Doing Good Always Lead to Doing Better? Consumer Reactions to Corporate Social Responsibility. Journal of Marketing Research, 38 (May), 225-243.

Sheth, Jagdish N., Nirmal K. Sethia, \& Shanthi Srinivas (2011). Mindful Consumption: A Customer-Centric Approach to Sustainability. Journal of the Academy of Marketing Science, 39 (1), 21-39.

Short, Jeremy C., David J. Ketchen, Timothy B. Palmer, \& G. Tomas M. Hult (2007). Firm, Strategic Group, and Industry Influences on Performance. Strategic Management Journal, 28 (2), 147-167. 
Singh, J., O. Iglesias, \& J. Batista-Foguet (2012). Does Having an Ethical Brand Matter? The Influence of Consumer Perceived Ethicality on Trust, Affect and Loyalty. Journal of Business Ethics, 111(4), 541-549.

Slater, Stanley F., G. Tomas M. Hult, \& Eric M. Olson (2007). On the Importance of Matching Strategic Behavior and Target Market Selection to Business Strategy in HighTech Markets. Journal of the Academy of Marketing Science, 35 (1), 5-17.

Slater, Stanley F. \& John C. Narver (1994). Does Competitive Environment Moderate the Market Orientation-Performance Relationship? Journal of Marketing, 58 (1), 46-55.

Smith, N. Craig, Minette E. Drumwright, \& Mary C. Gentile (2010). The New Marketing Myopia. Journal of Public Policy \& Marketing, 29 (1), 4-11.

Sorescu, Alina B. \& Jelena Spanjol (2008). Innovation's Effect on Firm Value and Risk: Insights from Consumer Packaged Goods. Journal of Marketing, 72 (March), 114-132.

Srivastava, Rajendra K., Tasadduq A. Shervani, \& Liam Fahey (1998). Market-Based Assets and Shareholder Value: A Framework for Analysis. Journal of Marketing, 62 (1), 2-18.

Stanaland, A.J., M.O. Lwin, \& P.E. Murphy (2011). Consumer perceptions of the antecedents and consequences of corporate social responsibility. Journal of Business Ethics, 102(1), 47-55.

Sudbury-Riley, Lynn \& Florian Kohlbacher (2016). Ethically minded consumer behavior: Scale review, development, and validation. Journal of Business Research, 69(8), 2697-2710.

Teece, David J., Gary Pisano, \& Amy Shuen (1997). Dynamic Capabilities and Strategic Management. Strategic Management Journal, 18 (7), 509-533.

Thomas, L.G., III \& Geoffrey Waring (1999). Competing Capitalisms: Capital Investment in American, German, and Japanese Firms. Strategic Management Journal, 20 (8), 729-748.

Tobin, James (1978). Monetary Policies and the Economy: The Transmission Mechanism. Southern Economic Journal, 44 (January), 421-431.

Torres, Anna, Tammo H. A. Bijmolt, Josep A. Tribó, \& Peter Verhoef (2012). Generating Global Brand Equity through Corporate Social Responsibility to Key Stakeholders. International Journal of Research in Marketing, 29(1), 13-24.

Toyota (2016). “2016 North America Environmental Report,” (accessed January 24, 2018), available at https://www.toyota.com/usa/environmentreport2016/

Toyota (2017). “Environmental Challenge 2050,” (accessed January 24, 2018), available at http://www.toyota.com/usa/environment/.

Trump, R. K. (2014). Connected consumers' responses to negative brand actions: The roles of transgression self-relevance and domain. Journal of Business Research, 67(9), 1824-1830.

Vargo, Stephen L. \& Robert F. Lusch (2004). Evolving to a New Dominant Logic for Marketing. Journal of Marketing, 68, 1-17. 
Vitell, Scott J., Robert Allen King, Katharine Howie, Jean-François Toti, Lumina Albert, Encarnación Ramos Hidalgo, \& Omneya Yacout (2016). Spirituality, Moral Identity, and Consumer Ethics: A Multi-cultural Study. Journal of Business Ethics, 139(1), 147-160.

Vomberg, Arnd, Christian Homburg, \&Torsten Bornemann (2015). Talented people and strong brands: The contribution of human capital and brand equity to firm value. Strategic Management Journal, 36(13), 2122-2131.

Vorhies, Douglas W. \& Neil A. Morgan (2003). Trading Off Between Value Creation and Value Appropriation: The Financial Implications of Shifts in Strategic Emphasis. Journal of Marketing, 67 (January), 100-115.

Waddock, Sandra \& Samuel B. Graves (1997). The Corporate Social Performance-Financial Performance Link. Strategic Management Journal, 18 (4), 303-319.

Wang, Zhan \& Hyun Gon Kim (2017). Can social media marketing improve customer relationship capabilities and firm performance? Dynamic capability perspective. Journal of Interactive Marketing, 39, 15-26.

Webster, Frederick E., Jr. (1992). The Changing Role of Marketing in the Corporation. Journal of Marketing, 56 (4), 1-17.

Wernerfelt, Birger (1984). A Resource-Based View of the Firm. Strategic Management Journal, 5 (2), 171-180.

Wilkie, William L. \& Elizabeth S. Moore (2011). Advancing the Study of Marketing in Society: JPP\&M as a Keystone of the Academic Infrastructure. Journal of Public Policy \& Marketing, 30 (1), 56-58.

Zeithaml, Valarie A., A. Parasuraman, \& Leonard L. Berry (1985). Problems and Strategies in Services Marketing. Journal of Marketing, 49 (2), 33-46. 
Table 1

Sample sizes of firms, strategic groups, and industries.

\begin{tabular}{|c|c|c|c|c|}
\hline \multirow[b]{2}{*}{ Sample } & \multirow[b]{2}{*}{$\begin{array}{l}\text { Level of } \\
\text { analysis }\end{array}$} & \multicolumn{3}{|c|}{ Focus of the strategic group } \\
\hline & & $\begin{array}{l}\text { Stakeholder- } \\
\text { focused } \\
\text { approach } \\
\end{array}$ & $\begin{array}{c}\text { Market-driven } \\
\text { approach }\end{array}$ & $\begin{array}{c}\text { Sustainability- } \\
\text { centered } \\
\text { approach } \\
\end{array}$ \\
\hline \multirow{3}{*}{$\begin{array}{r}\text { All } \\
\text { firms }\end{array}$} & Industry & 9 & 9 & 9 \\
\hline & Strategic group & 17 & 23 & 21 \\
\hline & Firm & 1716 & 1716 & 1716 \\
\hline \multirow{3}{*}{$\begin{array}{l}\text { Product } \\
\text { firms }\end{array}$} & Industry & 4 & 4 & 4 \\
\hline & Strategic group & 6 & 10 & 9 \\
\hline & Firm & 825 & 825 & 825 \\
\hline \multirow{3}{*}{$\begin{array}{r}\text { Service } \\
\text { firms }\end{array}$} & Industry & 5 & 5 & 5 \\
\hline & Strategic group & 11 & 13 & 12 \\
\hline & Firm & 891 & 891 & 891 \\
\hline \multirow{3}{*}{$\begin{array}{l}\text { High tech } \\
\text { firms }\end{array}$} & Industry & 3 & 3 & 3 \\
\hline & Strategic group & 7 & 9 & 7 \\
\hline & Firm & 317 & 317 & 317 \\
\hline \multirow{3}{*}{$\begin{array}{l}\text { Low/stable } \\
\text { tech firms }\end{array}$} & Industry & 9 & 9 & 9 \\
\hline & Strategic group & 17 & 23 & 21 \\
\hline & Firm & 1399 & 1399 & 1399 \\
\hline
\end{tabular}


Table 2

The effects of the firm, strategic group, and industry levels on firm performance (Tobin's Q).

\begin{tabular}{|c|c|c|c|c|c|c|c|}
\hline \multirow[b]{3}{*}{ Sample } & \multirow[b]{3}{*}{$\begin{array}{l}\text { Level of } \\
\text { analysis }\end{array}$} & \multicolumn{6}{|c|}{ Focus of the strategic group } \\
\hline & & \multicolumn{2}{|c|}{$\begin{array}{c}\text { Stakeholder- } \\
\text { focused approach }\end{array}$} & \multicolumn{2}{|c|}{$\begin{array}{l}\text { Market-driven } \\
\text { approach }\end{array}$} & \multicolumn{2}{|c|}{$\begin{array}{c}\text { Sustainability- } \\
\text { centered approach }\end{array}$} \\
\hline & & $\begin{array}{c}\text { Variance } \\
\text { component }\end{array}$ & $\begin{array}{l}\text { Percent } \\
\text { of total }\end{array}$ & $\begin{array}{c}\text { Variance } \\
\text { component }\end{array}$ & $\begin{array}{c}\text { Percent } \\
\text { of total }\end{array}$ & $\begin{array}{c}\text { Variance } \\
\text { component }\end{array}$ & $\begin{array}{l}\text { Percent } \\
\text { of total }\end{array}$ \\
\hline \multirow{4}{*}{$\begin{array}{r}\text { All } \\
\text { firms }\end{array}$} & Industry & 0.0185 & 0.0308 & 0.0377 & 0.0626 & 0.0380 & 0.0634 \\
\hline & Strategic group & 0.0335 & 0.0558 & 0.0106 & 0.0177 & 0.0085 & 0.0142 \\
\hline & Firm & 0.5487 & 0.9134 & 0.5528 & 0.9197 & 0.5534 & 0.9225 \\
\hline & Total & 0.6008 & 1.0000 & 0.6011 & 1.0000 & 0.5999 & 1.0000 \\
\hline \multirow{4}{*}{$\begin{array}{r}\text { Product } \\
\text { firms }\end{array}$} & Industry & 0.0241 & 0.0942 & 0.0202 & 0.0800 & 0.0216 & 0.0858 \\
\hline & Strategic group & 0.0020 & 0.0078 & 0.0050 & 0.0197 & 0.0055 & 0.0219 \\
\hline & Firm & 0.2295 & 0.8980 & 0.2275 & 0.9003 & 0.2250 & 0.8923 \\
\hline & Total & 0.2555 & 1.0000 & 0.2527 & 1.0000 & 0.2522 & 1.0000 \\
\hline \multirow{4}{*}{$\begin{array}{r}\text { Service } \\
\text { firms }\end{array}$} & Industry & 0.0158 & 0.0174 & 0.0431 & 0.0472 & 0.0457 & 0.0500 \\
\hline & Strategic group & 0.0447 & 0.0494 & 0.0154 & 0.0169 & 0.0087 & 0.0096 \\
\hline & Firm & 0.8456 & 0.9332 & 0.8546 & 0.9360 & 0.8583 & 0.9404 \\
\hline & Total & 0.9061 & 1.0000 & 0.9130 & 1.0000 & 0.9127 & 1.0000 \\
\hline \multirow{4}{*}{$\begin{array}{r}\text { High tech } \\
\text { firms }\end{array}$} & Industry & 0.0028 & 0.0072 & 0.0166 & 0.0427 & 0.0045 & 0.0116 \\
\hline & Strategic group & 0.0119 & 0.0307 & 0.0000 & 0.0001 & 0.0130 & 0.0338 \\
\hline & Firm & 0.3710 & 0.9621 & 0.3719 & 0.9572 & 0.3670 & 0.9546 \\
\hline & Total & 0.3856 & 1.0000 & 0.3886 & 1.0000 & 0.3844 & 1.0000 \\
\hline \multirow{4}{*}{$\begin{array}{r}\text { Low/stable } \\
\text { tech firms }\end{array}$} & Industry & 0.0167 & 0.0260 & 0.0367 & 0.0571 & 0.0410 & 0.0636 \\
\hline & Strategic group & 0.0401 & 0.0622 & 0.0132 & 0.0206 & 0.0079 & 0.0122 \\
\hline & Firm & 0.5871 & 0.9118 & 0.5927 & 0.9223 & 0.5954 & 0.9242 \\
\hline & Total & 0.6439 & 1.0000 & 0.6426 & 1.0000 & 0.6442 & 1.0000 \\
\hline
\end{tabular}


Table 3

The relative importance of firm, strategic group, and industry levels.

\begin{tabular}{|c|c|c|c|c|c|c|c|}
\hline \multirow[b]{3}{*}{ Sample } & \multirow[b]{3}{*}{$\begin{array}{l}\text { Level of } \\
\text { analysis }\end{array}$} & \multicolumn{6}{|c|}{ Focus of the strategic group } \\
\hline & & \multicolumn{2}{|c|}{$\begin{array}{c}\text { Stakeholder- } \\
\text { focused approach }\end{array}$} & \multicolumn{2}{|c|}{$\begin{array}{c}\text { Market-driven } \\
\text { approach }\end{array}$} & \multicolumn{2}{|c|}{$\begin{array}{c}\text { Sustainability- } \\
\text { centered approach }\end{array}$} \\
\hline & & $\begin{array}{c}\% \text { of } \\
\text { Variance } \\
\text { explained }\end{array}$ & $\begin{array}{l}\text { Relative } \\
\text { importance }\end{array}$ & $\begin{array}{c}\% \text { of } \\
\text { Variance } \\
\text { explained }\end{array}$ & $\begin{array}{l}\text { Relative } \\
\text { importance }\end{array}$ & $\begin{array}{c}\text { \% of } \\
\text { Variance } \\
\text { explained }\end{array}$ & $\begin{array}{l}\text { Relative } \\
\text { importance }\end{array}$ \\
\hline \multirow{4}{*}{$\begin{array}{r}\text { All } \\
\text { firms }\end{array}$} & Industry & 0.0308 & 0.1283 & 0.0626 & 0.1865 & 0.0634 & 0.1891 \\
\hline & Strategic group & 0.0558 & 0.1728 & 0.0177 & 0.0990 & 0.0142 & 0.0894 \\
\hline & Firm & 0.9134 & 0.6989 & 0.9197 & 0.7145 & 0.9225 & 0.7215 \\
\hline & Total & 1.0000 & 1.0000 & 1.0000 & 1.0000 & 1.0000 & 1.0000 \\
\hline \multirow{4}{*}{$\begin{array}{r}\text { Product } \\
\text { firms }\end{array}$} & Industry & 0.0942 & 0.2286 & 0.0800 & 0.2062 & 0.0858 & 0.2114 \\
\hline & Strategic group & 0.0078 & 0.0657 & 0.0197 & 0.1022 & 0.0219 & 0.1068 \\
\hline & Firm & 0.8980 & 0.7057 & 0.9003 & 0.6916 & 0.8923 & 0.6818 \\
\hline & Total & 1.0000 & 1.0000 & 1.0000 & 1.0000 & 1.0000 & 1.0000 \\
\hline \multirow{4}{*}{$\begin{array}{r}\text { Service } \\
\text { firms }\end{array}$} & Industry & 0.0174 & 0.1000 & 0.0472 & 0.1652 & 0.0500 & 0.1732 \\
\hline & Strategic group & 0.0494 & 0.1683 & 0.0169 & 0.0988 & 0.0096 & 0.0758 \\
\hline & Firm & 0.9332 & 0.7317 & 0.9360 & 0.7360 & 0.9404 & 0.7510 \\
\hline & Total & 1.0000 & 1.0000 & 1.0000 & 1.0000 & 1.0000 & 1.0000 \\
\hline \multirow{4}{*}{$\begin{array}{r}\text { High tech } \\
\text { firms }\end{array}$} & Industry & 0.0072 & 0.0682 & 0.0427 & 0.1731 & 0.0116 & 0.0849 \\
\hline & Strategic group & 0.0307 & 0.1413 & 0.0001 & 0.0074 & 0.0338 & 0.1449 \\
\hline & Firm & 0.9621 & 0.7905 & 0.9572 & 0.8196 & 0.9546 & 0.7702 \\
\hline & Total & 1.0000 & 1.0000 & 1.0000 & 1.0000 & 1.0000 & 1.0000 \\
\hline \multirow{4}{*}{$\begin{array}{r}\text { Low/stable } \\
\text { tech firms }\end{array}$} & Industry & 0.0260 & 0.1181 & 0.0571 & 0.1779 & 0.0636 & 0.1905 \\
\hline & Strategic group & 0.0622 & 0.1827 & 0.0206 & 0.1069 & 0.0122 & 0.0834 \\
\hline & Firm & 0.9118 & 0.6993 & 0.9223 & 0.7152 & 0.9242 & 0.7261 \\
\hline & Total & 1.0000 & 1.0000 & 1.0000 & 1.0000 & 1.0000 & 1.0000 \\
\hline
\end{tabular}


Fig. 1

A depiction of the multilevel modeling of effects at the firm, strategic group, and industry levels on firm performance.

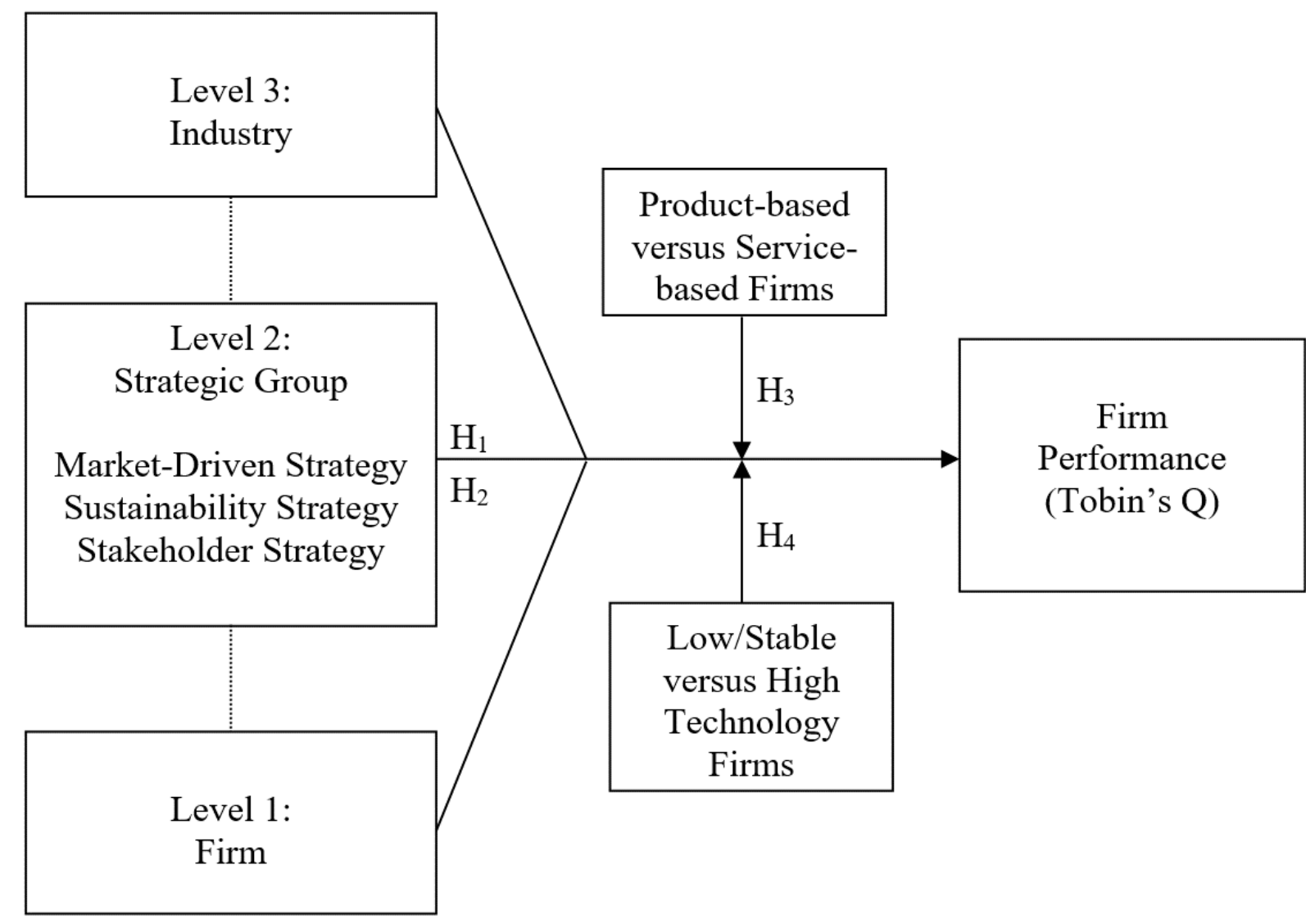

Time Period: $t_{0}$ to $t_{1}$ Time Period: $t_{2}$ to $t_{3}$ 